\title{
IGNACIO DE ANTIOQUÍA INVENTÓ EL CRISTIANISMO: TRAJANO Y ADRIANO FRENTE A LOS CRISTIANOS* IgNATIUS of ANTIOCH INVENTED THE CHRISTIANISM: TRAJAN AND HadRIAN FACING THE CHRISTIANS
}

\author{
Pedro Giménez de Aragón Sierra \\ Universidad Pablo de Olavide \\ PGIMSIE@UPO.ES
}

\section{RESUMEN}

Este artículo estudia el cambio conceptual que se produjo a partir de Ignacio de Antioquía, creador de los neologismos Christianismós y Katholika Ekklesía. Se analiza también el precedente que supuso el neologismo 'Ioudaïsmós, nacido en $2 \mathrm{Ma}$ cabeos. Por otra parte, se analiza la relación existente entre el nacimiento de una identidad cristiana a principios del siglo II y el cambio en la política religiosa de Adriano respecto a los cristianos. Si Trajano ordenó que los cristianos confesos debían ser ejecutados, Adriano, después de escuchar la

\begin{abstract}
This article deals with the conceptual change produced after Ignatius of Antioch, creator of the neologisms Christianismós and Katholika Ekklesía. The precedent that made arise the neologism 'Ioudaïsmós, born in 2Maccabees, is also analyzed. On the other hand, the relationship between the birth of a Christian identity at the beginning of the second century and the change of Hadrian's religious policy towards the Christians is analyzed as well. Whereas Trajan ordered that confessed Christians should be executed, Hadrian commanded, after having listen
\end{abstract}

\footnotetext{
* Este estudio se ha realizado dentro del proyecto "Adriano y la integración de la diversidad regional. Una perspectiva histórica e historiográfica” (HAR2015-65451-C2-1-P MINECO/FEDER).
} 
Apología de Arístides, ordenó que las ejecuciones debían cesar. Arístides y las cartas de Bernabé y 1 Pedro son textos cristianos de esa época que pugnan por la consolidación de una identidad cristiana diferente a la grecorromana y a la judía. Dicha identidad no era religiosa sino étnica, porque el concepto de religión tal como hoy lo conocemos no existía en la Antigüedad. the Apology of Aristides, that the executions should come to an end. Aristides and the letters of Barnabas and 1 Peter are Christian texts of that time that struggle for the consolidation of a Christian identity different from the Greco-Roman and Jewish identities. This identity was not religious but ethnic, since the concept of religion as we know it today did not exist in Antiquity.

\section{PALABRAS ClaVe}

Judaísmo, Cristianismo, Ignacio de Antioquía, Arístides de Atenas, Bernabé, 1 Pedro, Trajano, Adriano

\section{KeYWORDS}

Judaism, Christianity, Ignatius of Antioch, Aristides of Athens, Bernabe, 1 Peter, Trajan, Hadrian 


\section{INTRODUCCIÓN}

El título de este artículo es un homenaje al rabino antisionista norteamericano Daniel Boyarin, profesor de la Universidad de California en Berkeley, que ha defendido en diferentes lugares la "Invención del Judaísmo" por parte de los intelectuales cristianos de los siglo II-V. ${ }^{1}$ Probablemente por prudencia, Boyarin no ha tratado el tema de la "Invención del Cristianismo", aunque del estudio de su obra se extrae claramente la conclusión de que se separó del judaísmo sólo a partir del siglo II, cuando los creyentes en Cristo residentes en la Diáspora -que eran tanto de origen judío como gentil- se vieron en la necesidad de que el resto del mundo los diferenciase claramente de los rebeldes judíos de las Guerras de Quitos y Bar Kosiba. ${ }^{2}$ Su formulación provocativa del problema histórico en cuestión en los títulos de los artículos citados no debe distraer al lector de la principal conclusión de su trabajo: que los límites entre lo que actualmente concebimos como judaísmo y cristianismo no eran tan claros como a veces creemos, sino permeables y móviles, y que en realidad la separación de ambas religiones fue un proceso lento comenzado fundamentalmente en el siglo II, consolidado en los círculos intelectuales cristianos del siglo IV, y convertido en una realidad social ya a partir del siglo V.

1. Boyarin, 2001; Boyarin, 2004a; Boyarin, 2004b.

2. Para Boyarin, Jesús de Nazaret fue un judío observante de la Torá y Pablo de Tarso un judío celoso que nunca utilizó la palabra "cristiano", desconocida para él: Boyarin, 1994; Boyarin, 2012. No sólo comparto sus conclusiones, sino que además considero que lo mismo cabe decir de los autores cristianos anteriores a Ignacio de Antioquía, como defenderé más adelante. 
De hecho, los historiadores contemporáneos cometemos un error cuando concebimos el judaísmo de los siglos II a.C. al II d.C. como una religión, aplicando categorías modernas a realidades antiguas diferentes a las actuales. Nadie ha explicado mejor que el canadiense Steve Mason, actualmente profesor de "Religiones Antiguas Mediterráneas" en la Universidad de Groningen, cuál era el sentido de las palabras "religión", "judío" y "judaísmo" en la Antigüedad. ${ }^{3}$

El concepto actual de religión en el mundo occidental consiste en un sistema integrado de creencias y prácticas relacionado con lo divino, ${ }^{4}$ una categoría inexistente en la Antigüedad, época en la que la palabra latina religio, significaba simplemente "cultos y ritos practicados por un pueblo" y hacía referencia fundamentalmente a la organización de sacerdotes, templos y sacrificios. ${ }^{5}$ Cada populus ( $\varepsilon$ $\theta$ voc) tenía su religio. Ni las creencias ni la ética tenían que ver con la religio, sino con la filosofía, ${ }^{6}$ que no era ya étnica, sino que podía ser universal.

El concepto de "judío", que actualmente en español se usa tanto para identificar a un individuo perteneciente a un grupo étnico como a un individuo perteneciente a una religión (mientras en inglés se distingue entre judean, étnico, y jew, religioso), tenía en la Antigüedad un sentido exclusivamente étnico, pero con un matiz muy relacionado con la nacionalidad o ciudadanía; es decir, se relacionaba claramente al judío con un territorio, Judea, aunque se admitía el mantenimiento de la identidad étnica de aquellos judíos que vivían fuera de Judea y de aquellos gentiles que se convertían en judíos, pero entendiendo dicha conversión no como un cambio de religión, sino más bien como un cambio de nacionalidad o ciudadanía. ${ }^{7}$

3. Mason, 2007. Antes de Mason, abordaron el tema de la "religio" autores como Sachot o Smith. He tratado este tema con mayor profundidad en un capítulo de un libro dedicado a Arnaldo Momigliano: Giménez de Aragón, 2019a.

4. RAE: "conjunto de creencias o dogmas acerca de la divinidad, de sentimientos de veneración y temor hacia ella, de normas morales para la conducta individual y social, y de prácticas rituales, principalmente la oración y el sacrificio para darle culto".

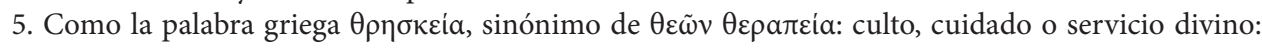
Mason, 2007, pp. 480-488.

6. De ahí que tanto los judíos Filón de Alejandría (Prob. 75-91; Vit. Cont. 2, 16) como Flavio Josefo (BJ II 119; AJ XIII 171-173 y XVIII 12) describiesen a esenios, terapeutas, fariseos y saduceos como "filósofos" y a sus escuelas de pensamiento como "filosofías". Todavía hoy, el mundo oriental prefiere aplicar el término "filosofía" a Hinduísmo, Sintoísmo o Budismo, rechazando la aplicación restrictiva occidental de "religiones" para dichas formas de pensamiento.

7. Aunque evidentemente el cambio "étnico" suponía un cambio de religio, puesto que cada pueblo tenía su religio, como sus mitos, historias, costumbres, fiestas, leyes, instituciones judiciales, estructuras sociales y sistemas políticos. Así, cuando la casa real de Adiabene se convirtió al judaísmo en la primera mitad del siglo I d.C., no sólo cambió de religio, sino que también transformó la cultura, la sociedad e 
Finalmente, el neologismo “judaísmo” - acuñado por Jasón de Cirene o su epitomista (el autor de 2Macabeos) para enfrentarlo al término "helenismo" (al que otorgó un sentido diferente al tradicional en las fuentes griegas $)^{8}$ - no tuvo en su origen el sentido de la categoría contemporánea de "religión", que no existía en la Antigüedad, ni siquiera el sentido amplio de civilización que damos hoy a "helenismo", 9 sino que,

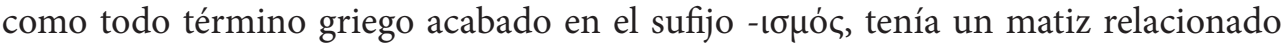
con los verbos en - $\zeta \zeta$, denotando la acción implicada, por lo que hay que entender que del mismo modo que Tucídides utilizaba "medismo" para referirse a los griegos que actuaban como medos o a favor de Persia y "aticismo" para los que no siendo ciudadanos atenienses actuaban en favor de Atenas (o los que hablaban como los atenienses), ${ }^{10}$ el autor de los neologismos “judaísmo" y "helenismo" se refería a la acción de actuar en favor de Israel y a la acción de actuar en favor de la Hélade. ${ }^{11}$ En efecto, los antiguos griegos usaban el término geográfico "Hélade" o el adjetivo "lo helénico" para definir su civilización, del mismo modo que los romanos utilizaban sólo "Roma” para definir la suya (sería un cristiano, Tertuliano, el que inventaría en latín un sustantivo abstracto para "civilización romana" en contraposición a "civilización cristiana”, pero en lugar de elegir el sufijo griego “-ismos”, seleccionó el propio del latín para entidades abstractas, “-as": "romanitas" y "christianitas", en español "romanidad" y "cristiandad"). ${ }^{12}$

incluso vinculó su sistema político al del antiguo Israel, transformándolo en una monarquía cuya casa real se vinculaba a Yahvé de la misma forma que lo hiciera el Rey David. En conclusión, cuando los antiguos hablaban de judíos se referían a un ع̋قvoc: Mason, 2007, pp. 489-510.

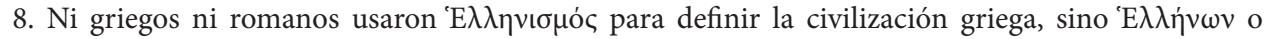
'E $\lambda \lambda \alpha_{\alpha} \varsigma$. El término 'E $\lambda \lambda \eta v v \sigma \mu o ́ c$, en fuentes griegas antiguas significaba "uso de una lengua y un estilo griego puro" (Diog. Bab. Stoic. 3, 214; Phld.Po. 2, 18; A.D.Pron. 71, 25; S.E.M. 1, 98; Lex.Vind. 311; Ath. 0.357a; Poxy. 1012 Fr 17). Sólo en la Tardoantigüedad el concepto adquirió el sentido de civilización o religión, como puede verse en Juliano: Ep. 84A; y en Cod. Just. I 11, 9, 1.

9. El concepto de "helenismo" como civilización surgida en el Imperio de Alejandro Magno después de su muerte gracias al sincretismo entre lo griego y lo oriental fue creado en el siglo XIX por Droyssen, 1834 (segunda edición de 1877-1878). Para profundizar en la historia e historiografía del término me remito a mi estudio ya citado en nota 3.

10. Tuc., III 61, 2 y $64,5$.

11. Ejemplos de verbos y sustantivos abstractos derivados de este modo son, por ejemplo: ỏotpakí $\omega_{\mathrm{t}}$

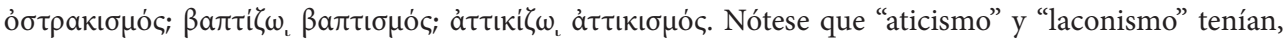
como "medismo", un sentido político-cultural, de actuar a favor de Atenas o Esparta, pero también un sentido lingüístico, de hablar como los atenienses o los espartanos. "Helenismo" en los textos griegos antiguos que se nos han conservado sólo tenía el sentido lingüístico. Es el autor de 2Macabeos el que lo usa añadiendo el matiz político-cultural, como acción en favor de la cultura o el Estado helénico. Mason, 2007, p. 460.

12. Tert., Pal. 4, 1. Cf. Den Boer et al., 1973. 
Este sentido sigue existiendo en las lenguas modernas, así, palabras como criticismo, exorcismo o culturismo son sustantivos abstractos que definen la acción del verbo del que proceden. Lo mismo ocurre con una segunda acepción de palabras actuales terminadas en -ismo: la del léxico o influencia idiomática, es decir, procedente de una lengua extranjera, como son los casos de anglicismo, galicismo, latinismo o hebraísmo. Pero en la antigua lengua griega no existían otros tres sentidos que actualmente se otorgan a determinadas palabras terminadas en -ismo:

- El de sistema o movimiento ideológico: anglicanismo, nacionalismo, hinduísmo, budismo, protestantismo, catolicismo, ateísmo, comunismo, marxismo, leninismo, liberalismo, fascismo, nazismo, etc.

- El de una forma de pensamiento discriminatoria basada en prejuicios: clasismo, racismo, sexismo, machismo, etc.

- El de una condición patológica: alcoholismo, reumatismo, paludismo, hipertiroidismo, etc.

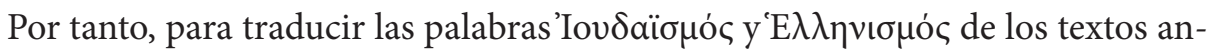
teriores al siglo II d.C. debería usarse preferiblemente "Judaización" y "Helenización", con sufijos de origen latino que indican acción verbal, que aluden a los dos únicos sentidos antiguos de los sufijos griegos en -ismós.

En cuanto al origen del cristianismo, entendido como religión, incluso sin aplicar estas premisas filológicas, resulta obvio para cualquier historiador que haya estudiado el tema que no fue un fenómeno creado ex-nihilo en un momento concreto de la Antigüedad, sino que fue generado lentamente a través de los siglos, desde la predicación de Jesús de Nazaret en Judea, pasando por la revisión de Pablo de Tarso en su misión a los gentiles, y separándose de la religión judía a partir del siglo II. Sin embargo, la aceptación del carácter procesual del nacimiento del cristianismo no debe

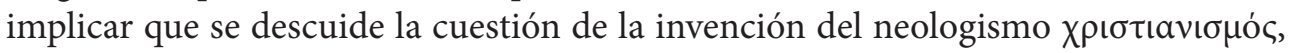
con todo lo que ello supuso.

El objetivo de este artículo es analizar cómo a principios del siglo II se acuñó el término "christianismós" para crear una nueva identidad capaz de separar totalmente a los fieles de Cristo del resto de fieles de Yahvé, no sólo a ojos de la propia comunidad cristiana, sino también en las mentes de los judíos no cristianos y en las de los gentiles, incluyendo las de los emperadores romanos. Y fue Ignacio de Antioquía en el siglo II d.C. el que acuñó el sustantivo abstracto y separó por primera vez la identidad cristiana de la judía, aplicando el sufijo "-ismós" al adjetivo "cristiano", como había hecho 2Macabeos en el siglo II a.C. con los términos "judaísmo" y "helenismo". 
Por otra parte, este trabajo pretende también demostrar que se produjo un cambio importante en la política de los emperadores Trajano y Adriano respecto a judíos y cristianos, y que en dicho cambio influyó sin duda la separación conceptual de judaísmo y cristianismo experimentada en las primeras décadas del siglo II. Si durante el Imperio de Trajano los cristianos fueron perseguidos "Deis Gratias", al final del reinado de Adriano se asentaban libres de toda persecución en una Jerusalén prohibida a los judíos por la gracia del dios-emperador.

\section{Primeros contactos de Trajano y Adriano con Judíos y Cristianos}

Algunos historiadores de la Antigüedad y exégetas cristianos y judíos cometen un error, desde mi punto de vista inaceptable, al juzgar la política religiosa de Trajano y Adriano considerando que no conocían suficientemente el pensamiento, las ideas y costumbres de judíos y cristianos. Tal percepción es consecuencia de la lectura de los textos clásicos coetáneos que hacen alusión a ambos grupos humanos, como es el caso de los pasajes de Plinio, Suetonio y Dión Casio relativos a judíos y cristianos. Se analizarán a continuación los contactos de la familia imperial con el mundo judeocristiano hasta el martirio de Ignacio de Antioquía, probablemente presenciado por Trajano y Adriano.

Para la familia de Trajano y Adriano judíos y cristianos no eran grupos humanos desconocidos ni despreciables. Marco Ulpio Trajano el Viejo fue el legado de la Legio X Fretensis que arrasó Galilea, Transjordania y Judea durante la guerra del 66 al $70 .{ }^{13}$ La X Fretensis no sólo se asentó en Jerusalén con su estandarte del águila y el jabalí (Júpiter y el cerdo en el lugar sagrado, la "abominación de la desolación" de Marcos 13), sino que sus cohortes se distribuyeron por el territorio ocupado, destacando la presencia en Cesarea de la Cohors II Italica Civium Romanorum, erróneamente considerada italiana. ${ }^{14}$ La procedencia de dicha cohorte de la ciudad de Itálica, patria de Trajano y Adriano, que ya planteara Jaime Alvar, ${ }^{15}$ es más lógica, puesto que en las legiones había varias cohortes procedentes de Italia, cada una con su denominación regional propia y no tendría sentido que una cohorte tuviera el nombre de toda Italia cuando las demás tenían nombres de ciudades o regiones

13. Canto, 2003.

14. CIL XVI 106; Hechos de los Apóstoles 10,1. La consideración de dicha cohorte como formada por ciudadanos romanos de Italia se debe a Ramsay, 1896; a quien siguen, entre otros, Broghton, 1933, p. 442; Saddington, 1982, p. 101; Speidel, 1992, p. 234.

15. Alvar, Gonzales y Giménez de Aragón, 2007, p. 408, n. 19. 
de Italia o de ciudades, regiones o tribus de Hispania y Mauritania. ${ }^{16}$ Además, de las cuatro cohortes de auxiliares constatadas en el período en que la X Fretensis fue la única legión con presencia en Judea (70-115), la mitad son hispanas. ${ }^{17}$ No hay que perder de vista que la X Fretensis fue reclutada por Augusto en Italia, Mauritania e Hispania para hacer frente a Marco Antonio, bajo cuyo mando estaba la famosa Legio X Equestris, llamada Gemina tras su derrota en Actium. Octavio había recurrido a los veteranos de las legiones cesarianas y a sus hijos, algunos asentados en colonias cesarianas provinciales como Híspalis y otros en Italia, para reivindicar la memoria de su padre. De ahí que los legados y centuriones de la X Fretensis durante los primeros siglos fueran occidentales a pesar de su permanencia durante décadas en Siria y Judea. ${ }^{18}$ Por otra parte, hay noticias antiguas sobre la identificación de la cohorte Itálica con la ciudad hispana. ${ }^{19}$

16. Al menos la mitad de las diez cohortes de las que solía estar compuesta una legión era de ciudadanos romanos. Nos consta en Judea la cohorte octava: LEG. FRET. COH. IIX, nombrada simplemente así, sin apelativos, en la inscripción del Museo de Israel en Jerusalén (Mor, 2016, p. 45, fig. 1.2). En otras legiones constan cohortes de regiones de Italia, por ejemplo la cohors I Campanorum voluntariorum civium Romanorum, asentada en Acumincum (Slankamen) desde época de Trajano (Lörincz, 2001, p. 51).

17. CIL XVI 33, diploma datado el 13 de mayo del 86: Cohortes II Cantabrorum, I Augusta Lusitanorum, I Thracum y II Thracum. También menciona dos alas de caballería que en sus orígenes debieron ser mauritanas: Veterana Gaetulorum y I Trachum Mauretana. Parece evidente que, con el tiempo, la legión reclutada en Occidente fue completándose con tropas auxiliares de Oriente, primero tracios, después sirios. Por cierto, quizás fuera a la Cohors I Augusta Lusitanorum a la que se refiriera Hch 27,1 cuando menciona al centurión Julio ante el que fue entregado Pablo en Cesarea, cuando menciona la $\sigma \pi \varepsilon i \rho \eta \varsigma \Sigma \varepsilon \beta a \sigma \tau \tilde{\eta}$.

18. Dabrowa, 1993, conclusión al respecto en p. 107.

19. Flavio Lucio Dextro, Chronicon Omnimodae Historiae: "C. Oppius centurio hispanus credit Christo morienti in cruce. Caius Cornelius, capharnaunensis dominus servi quem Dominus sanavit, pater etiam C. Oppii centurionis, erat hispanus, mire floret in Hispania. Floret per id tempus in Hispania C. Oppius C. F. C, pater centurio, qui morientem Christum praedicat Hierosolymis esse Filium Dei" (Ann. 34) "Cornelius Centurio italicensis cohortis, Petro praedicante, repletur Spiritu Santo prius, Hierosolymis denuntiata solemni gentilium ad fide Christi conversione, Cornelius vere baptizatus floret" (Ann. 40). Aunque los fragmentos de la obra escrita por Dextro en torno al año 400 y desaparecida en la Edad Media fueron publicados en 1619 tras su manipulación por el jesuita español Jerónimo Román de la Higuera en 1594, y por tanto se trata de una fuente no fiable, lo interesante aquí no es la existencia real de esos centuriones (ni siquiera es creíble la noticia de Lucas sobre la presencia de un centurión en Cafarnaum, dado que en tiempos de Jesús no había tropas romanas en Galilea, sino judías e idumeas bajo el mando de Herodes Antipas), sino la identificación de la cohorte Itálica con la ciudad bética, que no es exclusiva de Dextro, sino que también se deduce de la carta de Jerónimo del año 398 destinada a Lucinio Bético: "Verdaderamente se ha cumplido ahora en ti la palabra del Señor: 'muchos vendrán de Oriente y de Occidente y se recostarán en el seno de Abrahán. Cornelio, centurión de la cohorte itálica, prefiguraba ya entonces la fe de mi querido Lucinio. El apóstol Pablo escribe a los romanos: 'Cuando me dirija a España, espero veros al pasar y ser encaminado por vosotros hacia allá. Con frutos tan notables como tú, demostró lo 
El emperador Trajano tenía trece años cuando estalló la guerra, por lo que no es probable que acompañase a su padre en aquella guerra, pero su primo Publio Elio Adriano Afer, hijo de Adriano Marullino y de Ulpia (hermana de Trajano el Viejo), que tuvo como hijo al futuro emperador Adriano en el 76 y falleció en el año 86, debió nacer en torno al 46, por lo que tenía edad de participar en la guerra del 66 al 70. Alcanzó el rango de senador después de ejercer la pretura, y para llegar al máximo nivel del cursus honorum, debió desempeñar previamente diversos cargos militares en la cohorte de su ciudad natal y mucho más probablemente cuando su tío desempeñaba el cargo de legado de la X Fretensis. Su cognomen indica que realizó alguna hazaña importante en África, muy probablemente en Mauritania que es donde había conflictos bélicos por aquel entonces, provincia que seguramente gobernó después de ejercer el cargo de pretor en Roma. Pudo detentar el mismo cargo que Vespasiano otorgó en el año 75 a Sexto Sentio Ceciliano, "Legatus Augusti pro praetore ordinandae utriusque Mauretaniae. ${ }^{20}$ No sería raro que Adriano Afer ejerciera el gobierno de Mauritania poco antes de Ceciliano, entre 71 y 74, la misma época en que su tío Trajano el Viejo gobernaba la Bética, dada la vinculación de ambas provincias (por no mencionar los posibles intereses económicos de la familia de su mujer, Domicia Paulina, originaria de Cádiz, ciudad fenicia como Tingis y Lixus). La pacificación de Mauritania por los Flavios permitió la reconstrucción del Castellum de Tamuda en tiempos del emperador Trajano. ${ }^{21}$ Además, una parte

que buscaba en esa provincia" (Ep 71; traducción de Valero, 1993, p. 738). Finalmente, no debe olvidarse que el nomen Cornelius era muy común en Hispania, como ya señaló Caro, 1634, pp. 104-106.

20. AE 1941, 79; CIL IX 4194. Aunque la Mauritania Tingitania fue separada de la Mauritania Cesariense en el año 42 tras el asesinato por Calígula del rey mauritano Ptolomeo, hijo de Juba, y la rebelión de su liberto Aedemón, volvieron a reunirse bajo un mismo mando con Galba que nombró procurador de ambas a Albino en el 69. Sin embargo, ese mismo año de los cuatro emperadores Otón, sucesor de Galba, otorgó "a la provincia de la Bética los pueblos de los moros a título de regalo", hecho que provocó que Albino invadiese la Tingitania e incluso amenazase Hispania y "desdeñado el título de procurador, usurpaba las insignias de la realeza y el nombre de Juba", por lo que fue asesinado por orden del legado de la X Legión, Cluvio Rufo, que se ganó a los moros para Vitelio, sucesor de Otón (Tac., Hist. I 78 y II 58-59). Nótese que en toda esta compleja historia se aprecian los vínculos entre la cohorte Itálica de la $\mathrm{X}$ Legión, la Bética y la Tingitania.

21. La frontera de la Mauritania Tingitana con los mauri o bereberes independientes se situaba en el castellum de Tamuda, a pocos kilómetros de la actual Tetuán, construido a mediados del siglo I, destruido por el fuego pocas décadas después y reconstruido a principios del siglo II. Pero la situación volvería a complicarse en época de Antonino Pío, "cuando los mauri, que forman la mayor parte de los libios independientes, nómadas y enemigos más temibles aún que los escitas ya que no andan errantes en carromatos, van a lomos de sus caballos, en compañía de sus mujeres; cuando los mauri dieron comienzo a una guerra que no había sido declarada, él los expulsó de todo su país, obligándoles a huir a las partes más alejadas de Libia, al monte Atlas y hacia las gentes que habitan en él" (Paus., VIII 43, 3). La victoria 
importante de las cohortes de la Legión X Fretensis era mauritana. Esto, sumado al hecho de que el mando de la Legión X lo ejerciese Trajano el Viejo refuerza la hipótesis de que su sobrino Adriano Afer participase en la guerra judía. Quizás incluso se debiese a él la vinculación de la familia Ulpia con el senador romano de origen mauritano Lusio Quietus, líder de la tribu de los Baquates, que tiempo después sofocaría a sangre y fuego la rebelión de Judea en el año 117, recibiendo en su recuerdo el nombre de Guerra de Qitos en las fuentes rabínicas. ${ }^{22}$ Por otra parte, muchos legionarios mauritanos de la Legión $\mathrm{X}$ regresarían a sus casas tras licenciarse con esclavos judíos, al igual que los legionarios hispanos.

En cualquier caso, aunque la presencia de Adriano Afer en Judea sea hipotética, la de Trajano el Viejo es indiscutible, y su conocimiento de la región y su problemática política sería tal que, tras recompensarlo con el gobierno de la Bética en torno al 71, Vespasiano lo puso en el 74 al mando de Siria, justo cuando se produjo la instalación de la X Fretensis en Jerusalén, tras la rendición de Masadá. Fue entonces, probablemente, cuando se llevó a cabo la reordenación territorial de la zona, creándose la provincia de Judea y extirpando del antiguo territorio herodiano la Transjordania y Escitópolis con la creación de la Decápolis, ${ }^{23}$ y seguramente Trajano el Viejo tuvo mucho que ver con esta decisión, porque conocía la diversidad étnica y religiosa de la región, así como el funcionamiento de dicha legión y de sus cohortes de auxiliares, y pretendía disminuir las posibilidades de influencia de una nueva rebelión judía separando el limes oriental de Judea. Tampoco debe despreciarse el hecho de que probablemente sea a Trajano el Viejo y sus soldados a quienes se deba el establecimiento de los primeros judíos asentados en Hispania, merced a la venta de los esclavos capturados durante la guerra del 66-70. Durante su gobierno de la Bética, si no antes, tuvo la oportunidad de enviar muchos de sus esclavos judíos a sus propiedades del Valle del Guadalquivir, así como de enriquecerse vendiendo esclavos judíos a otros terratenientes de su patria. Y lo mismo harían muchos de sus soldados de la cohorte Itálica licenciados durante esos años.

Tanto Trajano como Adriano debieron recibir mucha información sobre los judíos y los cristianos de sus parientes. El joven Trajano que a sus diecisiete años se desplazaría a Roma durante el consulado de su padre, dispondría sin duda a partir de entonces de esclavos y esclavas judías obtenidos como botín por su padre.

de Antonino Pío no fue definitiva: poco después, en tiempos de Marco Aurelio, los mauri invadieron la Bética (HA, Marc. Aurel. 21, 2; HA, Sever. 2, 4). Cf. Gonzalbes, 1992; Gonzalbes, 2010, p. 45, n. 78.

22. Vanacker, 2013.

23. Giménez de Aragón, 2011. 
Por otra parte, Trajano debió vivir el incendio de Roma atribuido por Nerón a los cristianos, los efectos del mismo y las versiones contradictorias respecto a su causa todavía eran tema de conversación durante su infancia, como lo seguían siendo cuando Tácito redactó su obra, ya en época de Trajano.

Igualmente, a Trajano y Adriano debieron afectarles bastante los juicios de Domiciano contra los senadores simpatizantes con el judaísmo o el cristianismo (que todavía no estaban delimitados), especialmente el de Acilio Glabrión, que había sido colega de Trajano en el consulado en el año 91 y pertenecía a una antigua familia nobiliaria. ${ }^{24}$ Téngase en cuenta que el hijo de este senador fue cónsul durante el Imperio de Adriano, en el año 124 (iprecisamente el año de la estancia en Atenas de Adriano durante la que el filósofo cristiano Arístides le presentaría su Apología!), y a él se dirige Adriano por carta para aclararle cuestiones procesales, como consta en el Digesto (XLVIII 2, 12, 1), por lo que es evidente que la rehabilitación de esta familia "judaizante" fue absoluta y que sus miembros pudieron formar parte de los asesores de Trajano y Adriano en cuestiones judías.

El proceso de Flavio Clemente, cónsul durante el primer semestre del año 95 y primo del emperador Flavio Domiciano, lo experimentó Adriano en persona, puesto que entre 94 y 95 había ejercido tres cargos menores para iniciar su cursus honorum (decemvir stilibus iudicandis, praefectus feriarum Latinorum y sevir turmae equitum romanorum). ${ }^{25}$ Trajano, dados los vínculos de su padre con la familia Flavia, debió vivir profundamente la ejecución de Clemente, si bien desde la distancia, porque en aquel entonces ejercía como gobernador de Germania Superior. Ambos juicios se producirían porque Domiciano obligó a los altos cargos romanos a realizar sacrificios en su nombre como Deus et Dominus, divinizándose en vida contra la costumbre del culto imperial (apoteosis tras la defunción). El caso de Flavio Clemente debió comentarse en todos los rincones de la sociedad romana, y no sólo en el orden senatorial, dado que los hijos de Flavio Clemente y Flavia Domitila - hija de un pariente de Vespasiano - habían sido adoptados por el emperador,

24. HA, Hadr. 2, 2; Suet., Dom. 10, 2; 15, 1; 21. Cass. Dio, LXVII 14, 1-3. El primer cónsul constatado de su familia lo fue en el 191 a.C. (inscripción PIR A 67). Adriano acababa de regresar a Roma con Trajano en el 90, para iniciar la formación propia de un joven aristócrata romano, cuando su tutor fue nombrado cónsul junto a Acilio Glabrión.

25. Este último era uno de los seis jóvenes de familias senatoriales que capitaneaba los escuadrones de caballeros romanos que desfilaban ante el emperador, el Senado y el pueblo cada 15 de julio. Inmediatamente después Adriano sería enviado a Aquincum (Budapest) como tribuno laticlavo de la Legión II Auditrix. 
rebautizados como Tito y Domiciano, e instituidos como posibles herederos ${ }^{26}$ y que hubo aspectos relacionados con los judíos y cristianos en la muerte de Domiciano es algo indiscutible. ${ }^{27}$ Nótese que las fuentes no son claras respecto a la afiliación judía o cristiana de Glabrión y Clemente, evidentemente porque la separación entre cristianismo y judaísmo aún no era definitiva.

Aun así, la política de Trajano respecto a los cristianos fue bastante dura. Aunque no hubiese una persecución general como las de los siglos III y IV, la política de Trajano respecto a los cristianos fue implacable. ${ }^{28}$ En palabras de Eusebio de Cesarea "se volvió a levantar la persecución contra nosotros parcialmente y por ciudades, a causa de levantamientos populares" (HE III 32, 1). En Judea serían ajusticiados por el gobernador Ático el primo de Jesús, Simeón ben Cleofás, y los nietos de un hermano de Jesús llamado Judas, que habían ejercido el liderazgo de la comunidad judeocristiana de Judea y Transjordania (entre el 96 y el 107).$^{29}$ En Bitinia el gobernador Plinio ejecutaba en 110-111 a todo aquel que se declaraba cristiano independientemente de que no hubiese cometido delito alguno, tan sólo por ostentar el nombre de cristiano, y Trajano aprobaba esta forma de actuar, rechazando tan sólo las denuncias anónimas, tan frecuentes en época de Domiciano. Cualquier persona de la que se tuviese conocimiento que profesase el culto a Cristo debía ser procesada y condenada a muerte, a menos que se arrepintiera y sacrificara a los dioses (y probablemente también al emperador). Esto es lo que se deduce de su respuesta a la carta de Plinio. ${ }^{30}$ Es probable que también durante el gobierno de Trajano - o a principios del Imperio de Adriano -, fuese martirizado Dionisio Areopagita, el primer obispo de Atenas. ${ }^{31}$

26. Suet., Dom. 15, 1; Cass. Dio, LXVII 14; Euseb., Hist. Eccl. III, 18, 4.

27. Applebaum, 1974.

28. Para el debate sobre si hubo persecución de Trajano, véase Suarez, 2005; González, 2005; Baslez, 2007.

29. Aunque no consta ninguna implicación de Trajano al respecto, y la denuncia se sitúa en el marco de la Ley Flavia contra los descendientes de la Casa de David, lo cierto es que Domiciano había suspendido dicha ley al perdonar a los nietos de Judas, por lo que Ático estaría violando una sentencia imperial, con lo que es difícil presuponer que no hubiera consultado a Trajano al respecto. Las noticias históricas al respecto son muy cercanas en el tiempo a los hechos, dado que Eusebio cita literalmente a Hegesipo, historiador judeocristiano de tiempos de Adriano: Hist. Eccl. III, 19-20 y 32; IV, 5.

30. Ep. 98. Texto en latín en Blanco y Orlandis, 1954, p. 103. Santos Yagua, N. 1981, pp. 391-410; Teja, R., 1998, pp. 475-490.

31. Hch 17, 34; Euseb., Hist. Eccl. III, 4, 10 y IV, 23, 3. Quadrato y Arístides, que dirigieron sus apologías a Adriano en 124 para combatir las persecuciones sufridas hasta la fecha, dan noticia sobre los problemas sufridos por los cristianos de Atenas (Hist. Eccl. IV, 3). Las noticias medievales sobre el martirio de Dionisio Areopagita en París no tienen ninguna credibilidad, como la atribución a este de las obras del Pseudo-Dionisio, escritas en el siglo IV o el V. Sin embargo, Jerónimo en su Martirologium 
También es posible que la iglesia de la provincia de Asia hubiese sufrido persecuciones del tipo de la de Bitinia, puesto que la carta del gobernador Graniano a Adriano no se sitúa muy lejos cronológicamente de la muerte de Trajano en $117 .{ }^{32}$ En cuanto al martirio del obispo de Siria, Ignacio de Antioquía, figura principal de este artículo, disponemos de dos fechas posibles en las fuentes, pero en ambos casos la presencia no sólo de Trajano sino también de Adriano fue fundamental.

El Martyrium Ignatii, obra del siglo V, se contradice al respecto en dos pasajes, porque en uno dice que Trajano lo condenó el día 13 antes de las calendas de enero del año del consulado de Sura y Seneción, noveno del Imperio de Trajano, es decir, el 20 de diciembre del 107 y en otro que lo hizo cuando estaba en Antioquía por la Guerra Pártica. ${ }^{33}$ La primera datación concuerda con el Chronicon de Eusebio (conservado en latín por la traducción de Jerónimo, del siglo V) y la segunda con la Chronographia de Malalas de Antioquía (s. VI), que da la fecha del 13 de diciembre del $114 .^{34}$ Desde mi punto de vista, es más lógico inclinarse por la datación tardía, como ya hicieran Lighfoot y Harnack, ${ }^{35}$ no sólo porque Malalas demuestra en su obra conocer bien las tradiciones de su ciudad natal, sino también porque la primera, aparte de la contradicción propia del Martyrium que sitúa a Trajano invadiendo Partia en el 107, se basa probablemente en una lectura rigurosa del Chronicon de Eusebio, que dice así respecto al año décimo de Trajano: "Una persecución fue iniciada por Trajano contra los cristianos. Simón, el hijo de Cleofás, que había ejercido el episcopado de Jerusalén, fue ejecutado. Justo le sucedió. También Ignacio, obispo de la iglesia de Antioquía, enviado a Roma, fue entregado a las fieras. Le sucedió Herón”. ${ }^{36}$ De esta frase puede deducirse que la persecución empezó en el 107, pero no necesariamente que el martirio de Ignacio fuera el mismo año que el de Simón ben Cleofás, en que se inició la persecución. Además, Eusebio no tenía muy claras las fechas de la persecución de Trajano porque la ejecución de Simón ben Cleofás fue llevada a cabo por Tiberio Claudio Ático, padre de Herodes Ático, que ejerció de gobernador de Judea entre el 99 y el $103 .^{37}$ En cualquier caso, en ambas ocasiones Adriano debió vivir el

Vetus Romanum (PL 123, 344; 374) da la fecha del aniversario del martirio de Dionisio Areopagita (3 de octubre), dice que fue ordenado por los apóstoles (¿Pablo?), y menciona que murió en tiempos de Adriano después de sufrir terribles tormentos.

32. Euseb., Hist. Eccl. IV, 8, 6-9, 3. Álvaro D’Ors data el proconsulado en Asia del senador de origen hispano Quinto Licinio Silvano Graniano en 121-123. D'Ors, 1974, pp. 69-76.

33. Martyrium Ignatii II 1 y VII 1.

34. Malalas, Chron. 11, v. 117 (edición bilingüe en griego y latín de Dindorf, 1831, p. 275).

35. Lighfoot, 1883-1889, pp. 435-472; Harnack, 1929, pp. 28-35.

36. Euseb., Chron. ad annum 107. Traducción propia.

37. Smallwood, 1962, pp. 131-133. 
proceso de cerca, en el 107 porque era pretor ¡y fue él quien financió los juegos de aquel año!, ${ }^{38}$ y en el 114 porque acompañaba a Trajano en la Guerra y sería nombrado gobernador de Siria ese año o el siguiente. ${ }^{39}$ En palabras de Malalas, Ignacio "provocó la ira de Trajano por haberlo increpado", ${ }^{40}$ por lo que el emperador lo envió a Roma condenado a morir devorado por las fieras, hecho que provocó según Malalas un terremoto en Antioquía (también mencionado por Dión LXVIII 24, 1-25, 6). Adriano "se hallaba con el emperador Trajano por estar emparentado con él por matrimonio cuando la gran ciudad de Antioquía sufrió la cólera de Dios. Por aquellas fechas era senador" (había ejercido el consulado en 108). ${ }^{41}$ Allen Brent ha cuestionado recientemente el motivo por el que Ignacio fue encausado, proponiendo una crisis interna de la Iglesia de Antioquía como causa. ${ }^{42}$ Aunque es muy interesante el análisis que hace de la crisis en Antioquía entre una iglesia dirigida por presbíteros y otra monoepiscopal propuesta por Ignacio, no me resulta convincente que esa fuera causa suficiente para la intervención de las autoridades romana, aparte de que no hay argumentos por los que rechazar la visión transmitida por las fuentes, según las cuales Ignacio provocó la ira imperial.

Lo cierto es que la repercusión de las cartas del mártir en el mundo cristiano de la época fue considerable, y que el estado de ánimos que reflejan es muestra también del sentir generalizado de muchas comunidades cristianas de la Diáspora, como después se comentará. La evolución experimentada por el cristianismo en aquellos años - separándose del judaísmo - tuvo que llegarle a Adriano, ya fuese conociendo directamente el caso de Ignacio de Antioquía, ya fuese a través de los apologetas que se dirigieron posteriormente a él influidos por el pensamiento ignaciano, y pudo ser un factor importante del giro que dio a la política imperial respecto a judíos y

38. HA, Hadr. III detalla su cursus honorum: cuéstor en 101, miembro del círculo de confianza de Trajano en la Primera Guerra Dácica (101-102), tribuno de la plebe en 105, legado de la Legió I Minervia durante la Segunda Guerra Dacia (105-106), "alcanzando gran gloria por sus notables hazañas. Por este motivo Trajano le regaló el diamante que había recibido de Nerva, lo que lo elevó a candidato para sucederle. Hecho prétor durante el segundo consulado de Sura y Serviano, recibió de Trajano veinte millones de sestercios para que celebrase juegos". Hay un error: el autor de la Historia Augusta confunde el consulado de Sura y Serviano (102) con el de Sura y Seneción (107), ya que Adriano no pudo ser prétor al año siguiente de ser cuéstor ni antes de ejercer como tribuno de la plebe.

39. Cass. Dio, LXVIII 17, 2-3. Trajano partió de Roma a finales de octubre del 113, descansó en Atenas, donde se encontraba Adriano, y llegaron a Antioquía en enero de 114 y regresaron allí a finales de año, tras la conquista de Armenia y norte de Mesopotamia. Sería entonces, el 13 de dicembre, según Malalas, cuando se produciría el martirio de Ignacio.

40. Malalas, Chron. 11, v. 117 (edición de Dindorf, 1831, p. 276). Traducción propia.

41. Malalas, Chron. 11, v. 118 (edición de Dindorf, 1831, p. 278). Cf. Birley, 2010, pp. 270-278.

42. Brent, 2007, pp. 19-43. 
cristianos. Pero antes de profundizar en dicho cambio, hay que analizar obra y pensamiento de Ignacio de Antioquía. Hay motivos sobrados para argumentar que tuvo un papel fundamental en el nacimiento del cristianismo como religión diferenciada del judaísmo, no sólo porque creó un nuevo aparato conceptual al acuñar el neologismo "christianismós" para diferenciar la identidad cristiana de la judía, sino también porque usó por primera vez los términos "herejía" y "heterodoxia" para calificar a corrientes como el judeocristianismo y el docetismo y porque en sus cartas estableció el modelo de Iglesia jerárquica monoepiscopal asistida por presbíteros y diáconos frente a la estructura primitiva más anárquica que conocemos por la Didajé, con profetas y maestros.

\section{Ignacio de Antioquía y el CONCEPTO de “Christianismós”}

En los textos neotestamentarios el calificativo "christiano" aparece sólo tres veces: dos en Hechos (11, 26 y 26, 28), libro escrito entre el 100 y el 135, como han demostrado múltiples estudios, entre los que voy a destacar los de Barbara Shellard y Laura Nasrallah, ${ }^{43}$ y una en la Primera Carta de Pedro 4, 16, carta escrita en torno al $111 .{ }^{44}$

43. Shellard demostró de forma irrefutable que el autor de Hechos copia - a veces mal - a Flavio Josefo y debe en consecuencia datarse posteriormente a la publicación y difusión de sus obras, y Nashrallah planteó una interesante hipótesis que señala como motivación y objetivo de la obra la construcción de un cristianismo cosmopolita adaptado al helenismo y al Imperio Romano en el que Pablo actuaría de forma similar a Adriano, viajando por las ciudades griegas para constituir una especie de liga de comunidades cristianas similar a la liga panhelénica creada por el emperador: Shellard, 2002; Nashrallah, 2008. La tesis de la datación de Hechos en el siglo II fue defendida ya en el siglo XIX por Baur y reivindicada hace medio siglo por O'Neill, 1961, pp. 1-63. Actualmente la respaldan la mayoría de los expertos, como Mount, 2002; Penner, 2004; Pervo, 2006; Tyson, 2006; Mathhews, 2010; Dupertuis y Penner, 2013.

44. La carta está escrita por la iglesia de Roma, con el pseudónimo de Pedro, "a los que viven como extranjeros en la Dispersión: en el Ponto, Galacia, Capadocia, Asia y Bitinia” (1Pe 1, 1). La interpretación tradicional aceptaba que fue escrita por el apóstol Pedro durante la persecución de Nerón, pero esta fue local y no consta que hubiera en Anatolia persecuciones hasta época de Plinio. Por otra parte, la eclesiología, la teología y el lenguaje la sitúan a principios del siglo II. La datación de la carta en la persecución de Plinio en Bitinia se debe a Beare, 1947. Posteriormente, exégetas católicos y protestantes han argumentado contra la datación tardía basándose en que la carta no refleja ninguna persecución real y han tratado de datarla entre el 70 y el 95, admitiendo que es posterior a la destrucción de Jerusalén, motivo por el que se define a Roma como Babilonia (1Pe 5, 13). En este sentido, Cothenet, 1984, p. 11; Elliott, 2000, pp. 127-130. Para mí, sus argumentos no son convincente y el ambiente de persecución es indiscutible: "no os extrañéis por la prueba de fuego que se acerca para examinaros, como si os estuviese sucediendo algo sorprendentemente extraño. Antes bien, en la medida en que participáis de los sufrimientos de Cristo, alegraos ahora, para que podáis alegraros con alborozo cuando se revele su gloria. Si os ultrajan a causa del nombre de Cristo, cuán honorables sois, porque el Espíritu divino de la gloria mora entre vosotros. Que ninguno de vosotros sufra por ser un criminal, o un ladrón, o un malhechor 
Ni Pablo, que se define a sí mismo como judío en Rom 11, 1 (porque para Pablo no había contradicción entre judaísmo y cristianismo, concepto este último que ni siquiera imaginaba, sólo había una religión judía renovada por Cristo y practicada por judíos y gentiles temerosos de Dios), ni el Apocalipsis ${ }^{45}$ ni ninguno de los cuatro evangelistas conocían la palabra "cristiano", pero no sólo eso, sino que tampoco la conoció ni la usó Clemente de Roma en su Primera Carta a los Corintios, datada en torno al año 96. Mucho menos se utilizó el término "cristianismo" ni ningún otro parecido que definiese a la religión cristiana fuera del judaísmo. Porque evidentemente, no tenía entidad propia, diferente del judaísmo. El movimiento cristiano era sólo un tipo de judaísmo más, una "quinta filosofía” judía (parafraseando a Flavio Josefo, que a esenios, fariseos y saduceos añadió como "cuarta filosofía” la de los celotes), aunque sus fieles -como los esenios- se autoconsiderasen el "resto" elegido de Isaías, compuesto por judíos y gentiles convertidos, el Verus Israel.

o un delator. No obstante, si sufre por ser cristiano, que no se avergüence sino que glorifique a Dios por llevar ese nombre" (1Pe 4, 12-16). "Participar en los sufrimientos de Cristo" consiste sin duda en sufrir la tortura y la pena máxima. La cuestión del "nombre" también nos pone en contacto con la carta de Plinio a Trajano: “Es el mismo nombre de cristianos, independiente de todo otro crimen, lo que debe ser castigado, o los crímenes relacionados con ese nombre?". Este es, por otra parte, el texto de 1Pedro que nos ocupa, en el que se menciona la palabra "cristiano". Para la investigación sobre 1Pedro anterior a los años 90, Cothenet, 1988, pp. 3685-3712. Para las últimas décadas de investigación, Jobes, 2005, pp. 5-19; Elliott, 2013, pp. 5-19.

45. El conflicto entre cristianos y judíos en Asia Menor ya se apreciaba en dos cartas del Apocalipsis, una a la Iglesia de Esmirna: "Yo conozco tus obras, y tu tribulación, y tu pobreza (pero tú eres rico), y la blasfemia de los que se dicen ser judíos, y no lo son, mas son sinagoga de Satanás” (Ap 2, 9); y otra a la iglesia de Filadelfia, la ciudad fundada por Eumenes II de Pérgamo en honor de su hermano Atalo II Filadelfo, a 133 kilómetros al Este de Esmirna subiendo por un afluente del río Hermos: "He aquí, yo entrego de la sinagoga de Satanás a los que se dicen ser judíos y no lo son, sino que mienten; he aquí, yo haré que vengan y adoren delante de tus pies, y que reconozcan que yo te he amado (...) Al que venciere, yo lo haré columna en el templo de mi Dios, y nunca más saldrá de allí; y escribiré sobre él el nombre de mi Dios, y el nombre de la ciudad de mi Dios, la nueva Jerusalén, la cual desciende del cielo, de mi Dios y mi nombre nuevo" (Ap 3, 9 y 12). Lo más probable es que, cuando se habla de los judíos de la sinagoga de Satanás, se refiera a los fariseos de Yamnia, que en torno al 90, por iniciativa del nasí Gamaliel II, habían ordenado pronunciar tres veces diarias en las sinagogas la Birkat ha Minim o "Bendición contra los herejes", maldiciendo a los nozrim o "nazarenos", es decir, a los judeocristianos, para impedir su participación en las mismas. Ahora bien, nótese que el autor les niega el título de judíos, valorándolo pues como positivo, y los califica de "sinagoga de Satanás", reservando evidentemente para sí y los suyos, es decir, para los judeocristianos, el verdadero título de "judíos", el Verus Israel. Entre la época en que se redactarían las cartas a las siete iglesias de Asia que abren el Apocalipsis - unánimemente datadas en torno al 95 - y la época de las cartas de Ignacio, una o dos décadas posterior dependiendo de cuando se date el martirio, hay un abismo: Ignacio ya no reclama el título de "verdaderos judíos", sino que por el contrario, define al cristianismo en oposición al judaísmo. 
El concepto de "cristianismo" nació en oposición al concepto de "judaísmo". La palabra "judaísmo" no se encuentra en la Tanaj ni en el Talmud ni en la literatura rabínica antigua. Sólo a partir de la Edad Media se acuñaría el término hebreo yahadut, como traducción del término griego usado por los cristianos. Hasta entonces, la palabra para designar la religión judía era simplemente "Israel", que es la que utilizaban los textos judíos antiguos. La diferencia es clara: "Israel" es una palabra con un campo semántico mucho más amplio, que incluye no sólo una realidad religiosa sino también una realidad geográfica, política, cultural e incluso étnica. El hecho de que los rabinos antiguos no usasen la palabra "judaísmo" como un fenómeno exclusivamente religioso radicaba, por una parte en la inexistencia de la categoría moderna "religión", por otra parte en su reivindicación del derecho del pueblo judío a su tierra, a su independencia o autonomía, a sus leyes, fiestas y costumbres. Los cristianos, en cambio, harían compatible la identidad romana y la identidad cristiana, haciendo de la primera una identidad política (o nacional, o ciudadana), y de la segunda una identidad exclusivamente religiosa.

Pero, en realidad, el término "ioudaïsmós" no era para Ignacio de Antioquía un concepto exclusivamente religioso. Ya se ha dicho que apareció por vez primera en 2 Macabeos y su significado era mucho más amplio, consistiendo en el apoyo a lo judío, entendiendo por tal la cultura, la sociedad y el sistema político judío, es decir todos aquellos aspectos que integraban la civilización judía. El autor, por una parte, le otorga un nuevo uso al término "helenismós", palabra que hasta entonces se había usado exclusivamente en sentido lingüístico, haciendo un paralelo quizás irónico con el sentido político de "medismo", "aticismo" o "laconismo"; por otra parte, crea el neologismo "ioudaïsmós"; pero además, como ha destacado Silvie Honigman, ${ }^{46}$ crea otro neologismo, "alofilismo", relacionado con el amor a lo extranjero. La primera vez que aparece la palabra "judaísmo" es cuando el epitomista define el contenido de la obra de Jasón de Cirene en cinco libros: "La historia de Judas Macabeo y sus hermanos, de la purificación del gran Templo y de la dedicación del altar, así como las guerras contra Antíoco Epífanes y su hijo Eupátor, y las manifestaciones celestiales

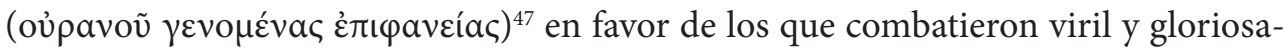

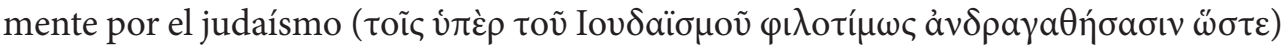
-los cuales, siendo pocos, liberaron a todo el país e hicieron huir a muchedumbres de extranjeros" (2M 2, 19-21). Como ya se ha dicho, sería más correcto traducir: "los

46. Honigman, 2014, p. 201, n. 17.

47. Nótese el juego de palabras del autor contraponiendo al sobrenombre de Antíoco IV las epifanías celestiales. 
que combatieron viril y gloriosamente por la Judaización", ya que la cita nos muestra

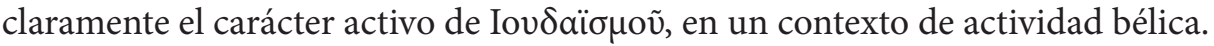

Para entender por qué era necesario judaizar al pueblo judío, hay que comprender que se había helenizado. Los términos "helenismós" y "alofilismós" aparecen justo después de explicar cómo Jasón, hermano del Sumo Sacerdote Onías III, sobornó a Antíoco IV para que le concediera el pontificado a cambio del privilegio de construir un gimnasio y una efebía: "Era tal el auge de la helenización y la extranjerización

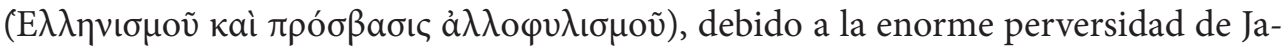
són - el cual tenía más de impío que de Sumo Sacerdote - que ya los sacerdotes no tenían ningún celo por el servicio del altar, sino que despreciaban el Templo. Apenas se daba la señal de lanzar el disco, dejaban de lado los sacrificios y se apresuraban a participar en los ejercicios de la palestra, que eran contrarios a la Ley" (2M 4, 13-14).

Así se entienden mejor los otros pasajes en que aparece el término "judaísmo": 2M 8, 1-5: "Mientras tanto, Judas Macabeo y sus compañeros, entraban clandestinamente en los pueblos, convocaban a sus familiares y, atrayendo a los que habían persistido en la Judaización, lograron reunir seis mil hombres"; y de 2M 14, 38: "Un tal Razís, uno de los ancianos de Jerusalén, buen patriota, sumamente estimado y llamado por su bondad "Padre de los judíos", fue denunciado a Nicanor. En el anterior período de confusión había sido acusado de judaísmo y se había entregado totalmente y con mucho entusiasmo a la defensa del judaísmo". "Judaización" significaba en aquel contexto lucha contra la helenización, contra la transformación del Templo de Yahvé en un templo a Zeus, contra el gimnasio, contra la efebía y contra la consecuente operación de epispasmos para reconstruir el prepucio que permitía a los judíos competir desnudos junto a los griegos sin que se percibiera la circuncisión.

Obviamente, cuando desapareció el peligro de helenización, tras la victoria de

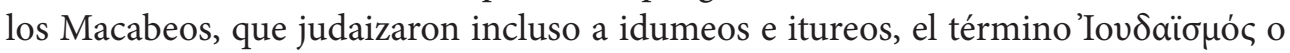
“judaización” dejó de ser necesario.

Esto explica que no vuelva a aparecer por escrito hasta doscientos años después, en la Carta a los gálatas de Pablo de Tarso: "Porque vosotros habéis oído acer-

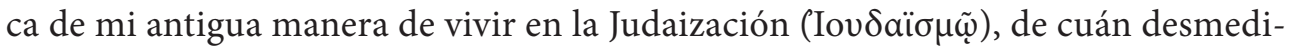
damente perseguía yo a la iglesia de Dios y trataba de destruirla y que adelantaba

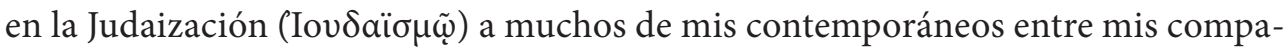

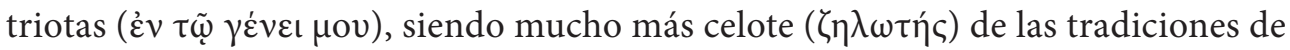
mis padres" (Gal 1, 13-14).

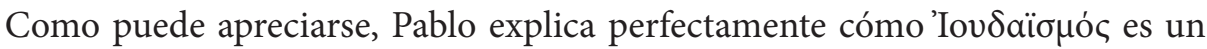
sustantivo abstracto relativo a la acción de perseguir como un celote a aquellos que se

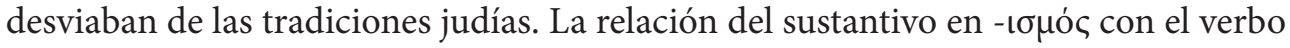
en - $\zeta \omega$ es aquí evidente, ya que Pablo usa el verbo "judaizar": "Pero cuando Pedro 
vino a Antioquía, le resistí en su cara, porque era de condenar. Porque antes que viniesen unos de parte de Jacobo, él comía con los gentiles, mas cuando vinieron, se retraía y se apartaba, teniendo miedo de los que eran de la circuncisión. Y otros judíos también disimulaban con él; de tal manera que también Bernabé fue llevado con su simulación. Pero cuando vi que no andaban rectamente conforme a la verdad del evangelio, dije a Pedro delante de todos: Si tú, siendo judío, vives como los gentiles y

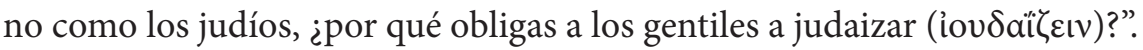

Al igual que en tiempos de los Macabeos, en época de Pablo se plantea de nuevo un problema en relación a la cultura judía, esta vez la de la Diáspora y en el sentido totalmente inverso al de entonces. Si en la época de los Macabeos el riesgo era la helenización del pueblo judío, en época de Pablo el problema era si la judaización de las etnias del mundo romano debía ser rigurosa o flexible. Se trataba de un problema teológico que para Pablo, que basaba su pensamiento en Isaías tanto como el propio Jesús, tenía su explicación clara en la profecía sobre las naciones. ${ }^{48}$ No había que circuncidar ni imponer a las naciones la cultura judía, no había que judaizarlas, sino simplemente permitirles adorar a su manera (con sus propios sacerdotes y levitas) a Yahvé, al templo de Jerusalén y a su Mesías. Pablo fue un visionario, vio claramente el futuro: el mundo romano se cristianizaría, no se judaizaría; o dicho de otro modo, se judaizaría un poco, pero no rigurosamente.

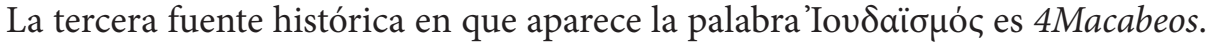
Esta obra, conservada en antiguos manuscritos del siglo IV y atestada por Eusebio de Cesarea a principios de ese siglo, ha sido atribuida por el propio Eusebio y otras múltiples fuentes eclesiásticas a Flavio Josefo, pero la crítica contemporánea, basándose en argumentos históricos y filológicos, considera que es obra de un autor anónimo del siglo I o de época de Adriano. Los partidarios de la datación temprana se basan en el hecho de que no se mencione la destrucción del Templo, pero esto es un argumentum ex silentio, es decir, una falacia cognitiva. Dupont, en cambio, argumenta a favor de la datación en época adrianea que el estilo es propio de la segunda sofística, que la noticia de pinturas en un lugar de culto no es propia del siglo $I(17,7)$ así como

48. Porque yo conozco sus obras y sus pensamientos; tiempo vendrá para juntar a todas las naciones y lenguas; y vendrán, y verán mi gloria. Y pondré entre ellos señal, y enviaré a los que escaparon de ellos a las naciones, a Tarsis, a Pul y Lud, que disparan arco, a Tubal y a Javán, a las islas apartadas que no oyeron de mí, ni vieron mi gloria; y publicarán mi gloria entre los gentiles. Y traerán a todos vuestros hermanos de entre todas las naciones, por ofrenda a Yahvé, en caballos, en carros, en literas, y en mulos y en camellos, a mi santo monte de Jerusalén, dice Yahvé, al modo que los hijos de Israel traen el presente en vasos limpios a la casa de Yahvé. Y tomaré también de ellos para sacerdotes y levitas, dice Yahvé (Is $66,18-21)$. 
el panorama de relativa calma propio de los primeros años del Imperio de Adriano, en que existió esperanza de reconstrucción del Templo, frente a los años finales de Trajano (Guerra de Qitos). ${ }^{49}$ La obra trata del martirio de Eleazar y los siete hermanos Macabeos junto con su madre. La exaltación del martirio también es propia de la época de Trajano, como destacan Epicteto (que habla del fanatismo de los galileos por el martirio) y el propio Ignacio en torno al $110,{ }^{50}$ por lo que Antíoco IV era un magnífico referente histórico: "Saqueó la ciudad y luego promulgó un decreto condenando a muerte a quienes parecieran conducirse de acuerdo con la ley de sus antepasados. Pero lejos de suprimir con sus decretos la observancia de la ley por parte del pueblo, vio que sus amenazas y castigos eran inútiles, hasta el punto de que algunas mujeres que habían circuncidado a sus hijos se arrojaban al vacío junto con las criaturas, conscientes de que esa era la suerte que los esperaba. Dado que sus decretos eran despreciados por el pueblo, él mismo obligaba con tormentos a cada ciudadano a comer alimentos impuros y renunciar al judaísmo" (4M 4, 23-25). Hay aquí cierto cambio de sentido de la palabra "judaísmo" porque no se refiere ya a una actitud de lucha, sino de resistencia pasiva. Se trataba de no renunciar a los principios de la propia cultura, del propio pueblo. Desde mi punto de vista, el concepto comenzaba a aproximarse al sentido actual de "judaísmo" como sistema, aunque todavía no como religión, categoría aún inexistente, sino como civilización.

Antes de analizar la forma en que Ignacio de Antioquía usó la palabra "judaísmo" y le opuso el neologismo "cristianismo", es necesario examinar su vinculación con la literatura de los Libros de los Macabeos. En Antioquía se celebraba el 1 de agosto una de las más antiguas fiestas cristianas en honor de los mártires Macabeos, aquellos siete hermanos que fueron torturados y ejecutados junto a su madre por no sacrificar a los dioses de Antíoco IV y por negarse a comer cerdo, tal como narran $2 \mathrm{M} 7$ y, más extensamente, 4 Macabeos. Malalas explica en su obra el martirio desde el punto de vista antioqueno: "Cuando Antíoco oyó lo que los judíos habían hecho en Jerusalén, como si se hubieran alegrado de su derrota, marchó contra Jerusalén. Sitió la ciudad y la capturó, matando a todos [los habitantes]; tomó a Eleazar el sumo sacerdote de los judíos junto con los Macabeos a Antioquía, donde los castigó con la muerte. Abolió el cargo de Gran Sacerdote de Judea, y convirtió el templo de los judíos, que había sido construido por Salomón, en un templo de Zeus Olímpico y

49. Dupont-Sommer, 1939, pp. 75-85.

50. La fecha de composición de las Diatribas se deduce de la biografía de Flavio Arriano de Nicomedia, senador y amigo de Adriano y uno de los grandes escritores de la época, que probablemente coincidió con él en la escuela de Epicteto en torno a esa fecha tomando apuntes que más tarde publicaría con el título de Diatribas de Epicteto. 
Atenea. Él profanó el edificio con la carne, e impidió a los judíos realizar sus ancestrales actos de adoración; durante tres años, los obligó a seguir las costumbres griegas. Cuando Antíoco murió, su hijo Antíoco Glauco, a quien llamaron Hierax, fue rey durante dos años. Después de él, Demetrio, el hijo de Seleuco, fue rey durante 8 años. Un judío llamado Judas vino a Antioquía la grande, y avergonzó a Demetrio con sus ruegos, de modo que el rey le devolvió el templo y los restos de los Macabeos. Judas sepultó a los Macabeos en el llamado Cerateum en Antioquía la grande, donde había una sinagoga de los judíos; Antíoco había castigado a los Macabeos en un corto camino fuera de la ciudad de Antioquía, en la montaña "que siempre llora" enfrente [del templo] de Zeus Casio. Entonces Judas limpió el templo y fundó de nuevo Jerusalén, celebrando una Pascua de los judíos [banquete] en honor a Dios". ${ }^{51}$ En el siglo IV incluso existía un templo consagrado a los mártires Macabeos, ${ }^{52}$ cuyas reliquias se trasladarían en el siglo VI a la cripta de la iglesia romana de San Pietro in Vincoli, construida en torno al 440 por iniciativa de Licinia Eudoxia, hija del Teodosio II de Constantinopla y esposa de Valentiniano III de Roma. El Itinerario de Antonino Placentino, escrito en torno al 570, describía aún la tumba de los mártires Macabeos en Antioquía como un panteón o columbario con nueve sepulcros. ${ }^{53}$

Independientemente de si 4 Macabeos es más o menos antigua que las Cartas de Ignacio de Antioquía, lo cierto es que en estas también se aprecia una forma diferente de entender la palabra "judaísmo", que aparece enfrentada al neologismo "cristianismo".

51. Malalas, Chron. 8, v. 37 (edición de Dindorf, 1831, pp. 204-205).

52. Agustin., Serm. 300, 3-6: "Aparece cierto judío y nos dice: ¿Cómo es que consideráis a estos mártires nuestros como vuestros, con qué desfachatez celebráis su memoria? (...) Si creyerais en Moisés, dijo, me creeríais también a mí, pues él escribió de mí. Si Moisés escribió de Cristo, quien en verdad murió por la Ley de Moisés entregó su vida por Cristo.(...) Así pues, los Macabeos son mártires de Cristo. En consecuencia, no está fuera de lógica ni es importuno, sino, al contrario, muy conveniente, que sean los cristianos quienes particularmente celebren solemnemente el día de su fiesta. ¿Celebran los judíos algo parecido? Se sabe que la basílica dedicada a los santos Macabeos se halla en Antioquía, es decir, en la misma ciudad que recibe su nombre del mismo rey perseguidor. En efecto, ellos tuvieron que sufrir a Antíoco, el impío rey perseguidor, y en Antioquía se celebra la memoria de su martirio, a fin de que resuene al mismo tiempo el nombre del perseguidor y la memoria del coronador. Tal basílica es propiedad de los cristianos, siendo los cristianos quienes la edificaron" (traducción de Pío de Luis Vizcaíno, Orden de San Agustín, www.augustinus.it). Agustín de Hipona escribió este sermón en torno al 400. Otras fuentes que mencionan la fiesta y basílica de los Macabeos en Antioquía son el Martirologio Siríaco (412), el Martirologio de Jerónimo (420), los Calendarios de Polemius Silvius (448), Gregorio Nacianzeno ( $P G \mathrm{XXXV}$ ), y algunas referencias en Juan Crisóstomo, Ambrosio de Milán, Gaudencio de Brescia y el Pseudoleón.

53. Gildemeister, 1889, p. 33: "nove exeuntes venimus Antiochiam Majorem, in qua requiescit sanctus Babylas et tres parvuli, sancta Justina et fratres Machabei, hoc est novem sepulcra et super uniuscujusque sepulcrum pendent tormenta ipsorum". 
Esta última aparece en tres de sus cartas: Magnesios 10, 1-3, Filadelfios 6, 1 y Romanos 3, 2. Filadelfios. Las Cartas de Ignacio de Antioquía han sido objeto de hipótesis peregrinas tanto en lo que se refiere a su autenticidad como en lo que afecta a su datación, ${ }^{54}$ aunque ninguna de estas ha utilizado argumentos realmente convincentes, de modo que la inmensa mayoría de los expertos aceptan la autenticidad y datación que el propio Eusebio de Cesarea dio al respecto dos siglos después de Ignacio, incluyendo los testimonios de Policarpo de Esmirna (mediados s. II) y su discípulo Ireneo de Lyon (segunda mitad s.II). ${ }^{55}$ En cuanto al objetivo de las cartas, pueden distinguirse tres grupos: Magnesios y Filadelfios luchan contra el judeocristianismo, Tralianos, Efesios, Esmirnotas y Policarpo son tratados contra los docetas mientras que Romanos, que se conserva y se transmite de un modo diferente, sin formar parte al principio de la colección de cartas asiáticas, carece de contenido antiherético y es más bien una apología del martirio. Si está escrita contra alguien, es contra Trajano (Rom 6,1 y 7,1 ), el emperador que condenó a Ignacio por haberle insultado públicamente (Malalas 11, 15).

54. Un buen resumen del debate sobre la "cuestión ignaciana" en los siglos XIX y XX en Ayán Calvo, 1999, pp. 39-74. Ni la hipótesis decimonónica de Cureton sobre la recensión breve siríaca ni la disparatada teoría de Weijenborg sobre la autoría de Evagrio Póntico ni la compleja pero indemostrable hipótesis de Rius-Camps sobre la duplicación de las cartas por un falsario ni el provocativo planteamiento de Robert Joly sobre la inexistencia de Ignacio, han tenido seguidores. Por el contrario, todas han sido rebatidas con sólidos argumentos. Véase también Schoedel, 1980, pp. 196-201; Schoedel, 1985. Si apenas ha tenido apoyo la datación temprana (80-100 d.C.) de las cartas ignacianas (Rius-Camps, 1977, pp. 31-149), la tendencia a datar más tarde la redacción de las mismas sí ha continuado. El mismo año de publicación de la obra de Ayán Calvo surgieron dos nuevas hipótesis retrasando la datación de las cartas ignacianas a la segunda mitad del siglo II: Hübner y Vincent, 1999; Lechner, 1999. Si Hübner y Vincent utilizaban para atrasar la fecha de las cartas su supuesto monarquianismo, Lechner planteó la hipótesis de la redacción de las cartas para combatir a los gnósticos valentinianos. Ambas teorías son forzadas, porque no disponemos de fuentes claras para conocer el pensamiento gnóstico anterior a los valentinianos (aunque el descubrimiento del Evangelio de Judas, un nuevo manuscrito gnóstico probablemente anteriores a Valentín, nos muestra que debió existir una teología gnóstica anterior bastante desarrollada). Por otra parte, de las cartas ignacianas tan sólo se extrae como conclusión la existencia de cierto docetismo, pero sin otras especulaciones propias del gnosticismo. Finalmente, estos autores ignoran argumentos sólidos en favor de la datación temprana, como la inexistencia de escritura sagrada cristiana en vida de Ignacio, la estructura eclesiástica en transformación, la cristología poco desarrollada, la citación de Ignacio por Policarpo de Esmirna y por Ireneo de Lyon, así como la conexión literaria y conceptual entre Ignacio y autores de la Segunda Sofística como Plutarco o Dión de Prusa, que florecieron entre el 80 y el 120 d.C.: Brent, 2006.

55. Euseb., Hist. Eccl. III 36. Ignacio escribió cuatro cartas desde Esmirna (tres a iglesias asiáticas Éfeso, Magnesia y Trales - y una a Roma) y tres desde Tróade (una a Filadelfia y dos a Esmirna, una a la comunidad y otra a su obispo, Policarpo). 
Todas las cartas de Ignacio tienen como objeto restaurar la unidad de las iglesias a las que escribe o, lo que es lo mismo, acabar con la pluralidad de pensamientos en las mismas e imponer un modelo único de cristianismo controlado por obispos, presbíteros y diáconos, según el modelo de los cultos mistéricos, como después se comentará. Pero véase ahora en qué contexto sitúa Ignacio las palabras "judaísmo" y "cristianismo". En Magnesios dice así:

"No os dejéis engañar por doctrinas extrañas ni por esos cuentos viejos que no sirven para nada. Porque si hasta el presente vivimos a estilo de judíos, confesamos no haber recibido la gracia. En efecto, los profetas divinísimos vivieron según Jesucristo. Por eso justamente fueron perseguidos, inspirados que fueron por su gracia, para convencer plenamente a los incrédulos de que hay un solo Dios, el cual se manifestó a sí mismo por medio de Jesucristo, su hijo, que es su Logos, procedente del silencio, que en todo agradó a Aquel que lo había enviado.

Ahora bien, si los que se habían criado en el antiguo orden de cosas vinieron a la novedad de esperanza, no guardando ya el sábado, sino viviendo según el domingo, día en que también amaneció nuestra vida por gracia del Señor y mérito de su muerte -misterio que algunos niegan, siendo así que por él recibimos la gracia de creer y por él sufrimos a fin de ser hallados discípulos de Jesucristo, nuestro solo Maestro-, ¿cómo podemos nosotros vivir fuera de Aquel a quien los mismos profetas, discípulos suyos que eran ya en espíritu, le esperaban como a su Maestro? Y por eso, el mismo a quien justamente esperaban, venido que fue, los resucitó de entre los muertos.

No nos endurezcamos, pues, para con su bondad; pues si Dios nos imitara a nosotros, según lo que obramos, ya pudiéramos darnos por no existentes. Por eso, pues nos hemos hecho discípulos suyos, aprendamos a vivir conforme al cristianismo. Porque todo el que otro nombre lleva, fuera del de cristiano, no es de Dios. Arrojad, pues, la mala levadura, vieja ya y agriada, y transformaos en la nueva, que es Jesucristo. Dejaos salar en Él, a fin de que nadie se corrompa entre vosotros, pues por vuestro olor seréis convictos. Absurda cosa es llevar a Jesucristo en la boca y vivir judaicamente. Porque no fue el cristianismo el que creyó en el judaísmo, sino el judaísmo en el cristianismo, en el que se ha consagrado toda lengua que cree en Dios.". ${ }^{56}$

Por otra parte, en Filadelfios ambos conceptos aparecen de nuevo en el contexto de una discusión con judeocristianos que argumentaban que no podían aceptar nada que no estuviera en las Escrituras sagradas judías, ni siquiera aunque estuviera en el Evangelio. Se refieren, en mi opinión, a la Tradición de Dichos, de tipo oral, ya

56. Magn 8, 9-10. Cf. Ruiz Bueno, 1979a. 
que Ignacio no cita ningún texto evangélico canónico, ${ }^{57}$ incluso incorpora un dicho desconocido por los canónicos, el de Esm 3,2, que sólo se encuentra en el Evangelio de los Hebreos citado por Jerónimo. No parece, pues, que Ignacio conociera ningún Evangelio escrito. Tan sólo parece indiscutible que usara una colección de cartas de Pablo, que cita más a menudo. Y los Profetas, citados todavía más. Pero, en cualquier caso, en la respuesta que da a los judeocristianos de Filadelfia sienta ya las bases para una nueva religión con sus propios textos sagrados: "para mí todos los archivos (textos sagrados) se cifran en Jesucristo" (Phil 8, 2b). Y aunque luego dice que se trata de archivos intangibles, puesto que no conoce aún una colección de textos sagrados cristianos, el argumento serviría a sus futuros lectores para subordinar la Escritura Antigua a aquella otra Escritura "cifrada" en Jesucristo.

El texto dice así:

Mas si alguno os viniera con interpretaciones sobre judaísmo, no le escuchéis. Porque más vale oír el cristianismo de labios de un hombre con circuncisión que no el judaísmo de labios de un incircunciso (...) Os lo advierto porque yo oí a algunos que decían:

- Si no lo encuentro en los archivos (se refiere a los textos sagrados judíos), lo que es en el Evangelio yo no lo creo.

Contesteles yo:

- Pues está escrito.

Y me respondieron ellos:

- Es lo que hay que probar.

Ahora bien, para mí todos los archivos se cifran en Jesucristo, los archivos intangibles son su cruz y su muerte, y su resurrección y la fe que en Él nos viene. En esos archivos quiero, por vuestra oración, ser justificado.

Buenos son, cierto, los sacerdotes; pero mejor es el Sumo Sacerdote, a quien le está confiado el santo de los santos, el solo a quien le han sido encomendados los secretos de Dios, como que Él es la puerta de Dios, por la que entran Abraham, Isaac y Jacob, los profetas, los Apóstoles y la Iglesia (Phil 6, 1 y 8, 1 - 9, 1).

Puesto que Ignacio no conocía ninguna Escritura cristiana, no extrajo su neologismo de los Hechos de los Apóstoles, obra probablemente posterior. Por otra parte, el uso que hace del concepto abstracto de judaísmo (así como del neologismo cristianismo) adquiere en él cierta personificación y pierde el carácter de

57. Sólo en la Carta a Policarpo, según Rius-Camp manipulada, encontramos un dicho completo: Pol 2, 2 = Mt 10, 6. El resto son palabras, giros, expresiones..., lo que no supone una clara demostración de uso del texto escrito, sino que puede reflejar simplemente tradición oral: Ef 11, $1 \mathrm{~b}=\mathrm{Mt} 3,7 ; \mathrm{Ef} 14,2 \mathrm{~b}=$ Mt 12, 33; Esm 1, 1c = Mt 3, 15; Esm 6, $1=$ Mt 19, 12. 
abstracción de una acción. Indiscutiblemente, traducir "no fue la cristianización la que creyó en la judaización, sino la judaización en la cristianización” carece de sentido. Aquí "judaísmo" y "cristianismo" han adquirido ya otro matiz, el que luego se difundirá entre los Padres de la Iglesia (Tertuliano y Orígenes primero, Eusebio, Epifanio y Agustín, después), el matiz de una entidad abstracta que engloba a las personas calificadas con el mismo nombre. "Judaísmo" se asemeja aquí a "Israel" (una civilización, una realidad étnica, cultural, social y política), pero al Vetus Israel, mientras que "cristianismo" es el Verus Israel que suplanta al antiguo. De ahí que hable de "cuentos viejos", del "antiguo orden de cosas" y de la "mala levadura, vieja ya y agriada" que hay que dejar por "la nueva, que es Jesucristo".

No debe olvidarse que Ignacio es claramente paulino. El conflicto entre los cristianos de origen judío y los de origen gentil en Antioquía se había producido, como es notorio, en época apostólica, entre Pedro y Pablo, recriminando este último al discípulo de Jesús que desde que habían llegado mensajeros de Santiago el hermano de Jesús ya no comía con los cristianos de origen gentil, tal como narra Pablo en el pasaje ya citado de Gálatas, donde además dice que Santiago le otorgó a él la misión sobre los gentiles y a Pedro la evangelización de los judíos.

Es digno destacar que según las Constituciones Apostólicas, Ignacio habría sido nombrado obispo por Pablo mientras que Pedro nombró a Evodio (VII 46). Un "inspector" para los cristianos gentiles y otro para los judeocristianos. Esta posibilidad es desde luego más plausible que la existencia de un monoepiscopado en Antioquía desde el principio, ya que en el siglo I el número de obispos o inspectores de una comunidad dependía de su tamaño y el monoepiscopado sólo se impondría a partir del siglo II, precisamente gracias a la defensa que de él hizo Ignacio, que debió en algún momento (quizás a la muerte de Evodio), lograr la unidad total de su comunidad, sin distinciones entre cristianos de origen judío o gentil, como defendía Pablo. 1 Clemente, por ejemplo, escrita por el secretario ab epistuli del consejo de presbíteros de Roma, habla de una iglesia de Corinto gobernada por el consejo de presbíteros: "someteos a los presbíteros" (1Cle 57, 1), mientras que los obispos aparecen como cargos secundarios similares a los diáconos (1Cle 42). Del mismo modo, en 1 Pedro, se aprecia que las provincias romanas de Anatolia estaban dirigidas por colegios de presbíteros remunerados $(1 \mathrm{Pe} 5,2)$. En ambos casos se trata de un paso en la evolución desde las iglesias anteriores a la Didajé, controladas por profetas y maestros. No había monoepiscopado ni en Roma, ni en Corinto, ni en las provincias anatólicas en torno al año 100. De las cartas troyanas de Ignacio se desprende que la unidad y la paz no se logró en la iglesia de Antioquía hasta su captura y envío a Roma (Filadelfios, Esmirnotas y Policarpo), por lo que es muy posible que hubiera ciertas divisiones entre judeocristianos, católicos y docetas. La unidad era también el objetivo que per- 
seguía con las cartas a las iglesias de la provincia de Asia, entendiéndose por unidad la necesidad de acabar con la pluralidad de corrientes en las comunidades cristianas. Ignacio pensaba que debía lograrse no sólo combatiendo las ideas de docetas y judeocristianos, sino también favoreciendo la imposición del modelo de iglesia que él había implantado en Antioquía y temía desapareciera (Rom 9, 1).

En cualquier caso, lo que Ignacio hizo fue aplicar el mismo criterio usado por 2 Macabeos para definir de forma enfrentada dos realidades culturales, de modo que no existiesen posturas intermedias. Si 2 Macabeos enfrentaba Israel a la Hélade y deseaba eliminar las posturas intermedias entre helenistas y hasidíes (como la del Sumo Sacerdote Alcimos), Ignacio enfrentaba en estas cartas cristianismo y judaísmo, deseando eliminar la postura intermedia del judeocristianismo. Si 2Macabeos utilizó el término "judaísmo" no para suplantar al de "Israel", sino para definir la acción de apoyo a una causa étnica, de modo similar al que Tucídides había usado con los términos "medismo" y "aticismo", Ignacio ya no usa estos términos terminados en -ismo como forma abstracta de referirse a una acción, sino como forma abstracta de referirse a una realidad humana que ya no era étnica ni geográfica, porque los cristianos ya no eran un pueblo con un referente geográfico claro.

Lo mismo apreciamos en su Carta a los Romanos, la carta de Ignacio más original porque en ella ni se habla de jerarquía eclesiástica (quizás conocía que la iglesia romana aún no estaba regida por el monoepiscopado, y no se atrevía a intentar imponer directrices organizativas a la iglesia de la capital), ni de disensiones entre judeocristianos, católicos y docetas (probablemente porque ignoraba si tales tendencias existían en Roma), sino de sus ansias de martirio. Sin embargo, utiliza también aquí el concepto "cristianismo". En un contexto diferente, pero con un objetivo similar: "Cuando el cristianismo es odiado por el mundo, la hazaña que le cumple realizar no es mostrar elocuencia de palabra, sino grandeza de alma" (Rom 3, 3b). Frente a "cristianismo", no encontramos aquí ni "judaísmo" ni "helenismo", concepto este último que no tendría sentido usar al dirigirse a los romanos. $Y$ hasta Tertuliano no aparece el concepto de romanitas. Por tanto, se enfrenta "cristianismo" a "mundo", el primer término usado ahora como concepto que engloba al conjunto de individuos que profesaban la religión de Cristo, mientras que el segundo término se refería al resto de los seres humanos, incluyendo a judíos y paganos. En cualquier caso, el objetivo sigue siendo otorgar a los cristianos una identidad propia, diferente de la de los judíos, de la de los griegos, de la de los romanos y, en definitiva, de cualquiera de las naciones o etnias. Probablemente de forma inconsciente, al acuñar el neologismo "christianismós" estaba creando un nuevo tipo de identidad diferente a la identidad étnica, una identidad religiosa. 
Pero como ya se ha anticipado, Ignacio de Antioquía no sólo fue el inventor del cristianismo en el sentido filológico, sino que además fomentó una nueva iglesia estructurada al estilo de los cultos mistéricos e incluso creó para definirla otro neologismo fundamental en la Historia del Cristianismo: el de "Iglesia Católica", que aparece por primera vez en la literatura cristiana en su Carta a los esmirnotas: "Donde aparezca el obispo, allí esté la comunidad, así como donde está Jesucristo, allí está la Iglesia católica", palabra que ha sido interpretada en seis posibles sentidos: ${ }^{58}$ 1. Geográfico, como universal; 2. Doctrinal, como ortodoxia frente a herejía; 3. Espiritual, como Iglesia invisible que debe ser imitada por la Iglesia terrestre; 4. Alegórico, aplicada a las iglesias locales en el sentido de plenitud alcanzada por la presencia de Cristo, como la usan los teólogos ortodoxos hoy día; 5. Absoluto, como sinónimo de plenitud o perfección; 6. Pleonástico, para designar la Iglesia en su totalidad. Aunque me inclino preferentemente por la definición pleonástica de André De Halleux, ${ }^{59}$ no creo que todos estos sentidos sean incompatibles entre sí, sino que matices de todas estas interpretaciones pudieron estar en la mente del autor al acuñar el término. Pero lo que realmente interesa destacar aquí es que, frente a un desarrollo hasta entonces local de las comunidades cristianas, que usaban el término "ekklesía" propio de los sistemas políticos municipales de las polis griegas para definir sus asambleas, Ignacio otorga al concepto de "iglesia" un sentido completamente nuevo, como federación de comunidades de seguidores de Cristo que deben compartir doctrinas y estructuras jerárquicas.

En este sentido, se ha atribuido a Ignacio el origen del episcopado monárquico, ${ }^{60}$ pero como ha demostrado recientemente Allen Brent, en realidad el tipo de estructura eclesiástica ignaciano difería del episcopado monárquico posterior en que no había una preeminencia absoluta y jerárquica por parte de los obispos de Siria y Asia en época de Ignacio, sino más bien se considera a obispos, presbíteros y diáconos como iguales y colegas, reflejando una forma de funcionamiento de las iglesias mediante órganos colegiados más que a través de órganos unipersonales. El análisis realizado por Brent sobre la forma que tienen la Didascalia y las Constituciones Apostólicas de citar a Ignacio demuestra la diferencia conceptual respecto a la jerarquía entre estas

58. Esm 8, 2. Traducción de Ayán Calvo, 1999, p. 86, en que explica los seis posibles sentidos de la palabra.

59. Halleux, 1982, pp. 5-24. Véase también Garciadiego, 1953.

60. Gryson, 1929, pp. 446-453; McArthur, 1961, pp. 298-304; McArthy, 1971, pp. 319-325; Trevett, 1983, pp. 1-18. 
obras tardoantiguas y la época de Ignacio. ${ }^{61}$ Las procesiones de los cultos mistéricos con sus portadores de las imágenes de los dioses, ${ }^{62}$ así como las procesiones del culto imperial con los portadores de las imágenes de los emperadores ${ }^{63}$ tienen su paralelo en las procesiones cristianas de época ignaciana, en las que los obispos eran la imagen del Dios Padre, los presbíteros los representantes del Colegio Apostólico o del Espíritu y los diáconos los representantes del Hijo. ${ }^{64}$ Esto explica mejor el significado del sobrenombre Teóforo que Ignacio se da a sí mismo en el encabezamiento de sus cartas (sin excluir otros sentidos posibles y compatibles del término, como sinónimo de mártir, testigo de Dios ante los tribunales imperiales y las ciudades por las que pasa durante su proceso).

Sin embargo, la comparación del obispo con Dios Padre no se limita a las procesiones, sino que se llega a calificar a Dios como "obispo de todos" ${ }^{65}$ por lo que es necesario matizar la situación.

En favor del argumento sobre el poder colegial de obispos y presbíteros se pueden aportar las citas en las que Ignacio encomienda a los cristianos de las distintas ciudades que se sometan al obispo y al colegio de ancianos. ${ }^{66}$ Esto parece indicar que ambas instituciones son iguales en poder. Sin embargo, la sumisión de los diáconos a obispos y presbíteros, es clara. ${ }^{67}$

Ahora bien, hay que destacar que si bien no hay episcopado monárquico, con un poder absoluto de los obispos sobre los presbíteros, sí hay un monoepiscopado en todas las ciudades mencionadas, lo cual supone una evolución respecto a los años anteriores, en los que cada comunidad tenía varios "inspectores", como se apreciaba en 1 Clemente y 1 Pedro. Probablemente, la figura de los inspectores u obispos nació al principio como necesidad de inspeccionar desde la metrópoli (Antioquía, Roma, Alejandría...) la corrección del culto y la doctrina impartida en los pueblos y ciudades de la provincia de dicha metrópoli. De ahí que fueran necesarios varios inspectores para cumplir esta función, que conllevaba la obligación de viajar por la provincia inspeccionando, algo que no podía desempeñar un sólo individuo. El Colegio de An-

61. Interesante, por ejemplo, cómo cambian typos por topos, "imagen" por "lugar", de modo que la atribución ignaciana de funciones representativas de imágenes a obispos, presbíteros y diáconos en las procesiones cristianas, se transformó en lugares ocupados por los tres tipos de cargos en las basílicas tardoantiguas. Cf. Brent, 2006, pp. 38-117.

62. Brent, 2006, pp. 121-230.

63. Brent, 2006, pp. 231-311.

64. Tral $3,1$.

65. Magn 3, 1 .

66. Ef 5, 1 - 6, 2; Magn 2, 1 - 3, 2; Tral 7, 2; Esm 8, 1-2; Poli 6, 1-2.

67. Magn 2, 1 (se ensalza al diácono Soción por someterse al obispo y al colegio de ancianos). 
cianos, como el Senado romano, designaba inspectores para desempeñar esa función, pero el poder residía fundamentalmente en dicho órgano colegial. Con el tiempo, cada ciudad de la provincia tuvo su comunidad cristiana suficientemente numerosa y se dotó de obispo propio para supervisar los pueblos y aldeas vecinos. Este sería el panorama de Asia en tiempos de Ignacio. En cambio en Siria, dado que Ignacio se denomina a sí mismo obispo de Antioquía y obispo de Siria, es probable que la evolución fuera distinta. Ya mencionamos antes la posibilidad de que hubiera en origen un obispo para los cristianos judíos y otro para los gentiles, pero de las cartas de Ignacio se concluye que en sus tiempos él era el único obispo. Se habría dado pues una evolución diferente hacia el monoepiscopado con la fusión de la función episcopal para ambas comunidades que vivían en Antioquía y Siria, los cristianos judíos y los cristianos gentiles. En ambos casos, al final se consolida el monoepiscopado.

Una lectura negativa de las cartas ignacianas nos describiría la situación de transición desde una iglesia gobernada por colegios de ancianos hacia una iglesia gobernada por un episcopado monárquico: puesto que es necesario que Ignacio ordene o encomiende a las comunidades a las que se dirige que obedezcan a los obispos, hay que deducir que el poder de los obispos en aquella época era muy relativo.

En cualquier caso, el hecho de que los cristianos aceptasen la propuesta de Ignacio de organizarse de un modo similar a las religiones mistéricas, adoptando un culto procesional parecido al de otros cultos griegos y romanos, así como la creación de nuevas catogorías conceptuales capaces de separar a los cristianos de los judíos tanto en la mente de las autoridades romanas como de los propios judíos y cristianos, debe situarse en el contexto de una época en que no sólo los emperadores sino también los sabios de la Segunda Sofística comenzaban a considerar posible un cambio identitario en los pueblos del Imperio.

El emperador Adriano, que fomentaba la formación de una identidad romana sincrética en la que se mezclasen elementos latinos con griegos y egipcios, ${ }^{68}$ una identidad cosmopolita, recibiría a los cristianos para escuchar su nuevo planteamiento sobre la identidad propia.

68. Sobre el fomento de la religión griega, Gordillo, 2012; sobre el de la religión egipcia, Muñiz, 2009. 


\section{LA NUEVA POLÍ́tica de AdRIANO RESPECTO A JUdíos y CRISTIANOS}

Siendo Adriano gobernador de Siria, tras la conquista por parte de Trajano del reino judío de Adiabene en primavera del 115, estalló a finales del verano de aquel año un conflicto entre judíos y griegos en Alejandría porque Trajano había favorecido a los judíos, sin embargo el Prefecto de Egipto, Rutilio Lupo, intervino contra ellos y promulgó un edicto el 13 de octubre ordenando paz en tanto llegaba un juez especial enviado por Trajano. ${ }^{69}$ Pero el emperador estaba entonces en plena conquista de Mesopotamia y no atendió dicha petición, con lo cual estalló una gran rebelión judía que se extendió desde Egipto a las provincias vecinas de Cirenaica, Chipre y Judea, donde fue denominada por los rabinos "Guerra de Qitos", por el nombre del gobernador de Judea encargado por Trajano de la represión, Lusio Quieto. La rebelión también llegó a Mesopotamia, donde se encontraba Trajano. Siria, en cambio, probablemente gracias al trabajo de su gobernador, Adriano, se mantuvo al margen. Es posible que Adriano se reuniera por aquel entonces con el sucesor de Ignacio en el episcopado de Antioquía, Herón, diácono de Ignacio sólo conocido por la mención de Eusebio y por una carta de Ignacio a él dirigida y unánimemente considerada apócrifa. No debe despreciarse que en una posible entrevista con Herón en el 115-116 Adriano recibiera ya una primera defensa del cristianismo como identidad cultural diferente del judaísmo, en la línea de las cartas de Ignacio ya comentadas, dado que nos consta que al futuro emperador le gustaba reunirse con los representantes de las distintas corrientes de pensamiento, como demuestran las noticias respecto a sus reuniones con filósofos griegos, rabinos fariseos, maestros samaritanos y apologetas cristianos.

Muerto Trajano en 117, Adriano decretó la sustitución como gobernador de Egipto a Rutilio Lupo por su hombre de confianza en temas militares, Quinto Marcio Turbo, que pacificó Egipto a principios de 117; enviándolo poco después a Judea para sustituir al gobernador Lusio Quieto (mientras enviaba a Egipto a Q. Rammio Martialis)..$^{70}$ Esto, unido a la política benefactora y urbanizadora de Adriano en Egipto, Galilea, Samaría y Judea ${ }^{71}$ explica que fuese tratado como un libertador en diver-

69. Papiro CPJ 435; Barnes, 1989, p. 153.

70. Syme, 1962, pp. 87-96. Syme plantea la posibilidad de que Turbo fuera el centurión primus pilus de la Legión II Adiutris en que Adriano comenzó su carrera militar como tribuno laticlavo en 95-96. Los jóvenes nobles romanos solían apoyarse en suboficiales de larga experiencia para ejercer como oficiales.

71. A la famosa construcción de la nueva ciudad de Antinoopolis en Egipto debemos añadir en Galilea la reconstrucción de Diocesarea (Séforis) y la edificación de un Hadrianeum en Tiberíades, en Samaría la reconstrucción del Templo del Monte Garizim, y en Judea la reconstrucción de Jerusalén. Miller, 1996, pp. 21-27; Belayche, 2001, p. 180; Evans, 2011, pp. 170-182. 
sas fuentes judías: Midrás Génesis Rabbá $(64,10)$, V Oráculo Sibilino $(36,41,44,48)$ y Papiro 158 del CPJ.

Poco después, en 122 se produce la situación que lleva a Adriano a modificar la legislación trajanea. Eusebio ${ }^{72}$ explica cómo el procónsul de Asia de los años 121-122, Q. Licinio Silvano Graniano, ${ }^{73}$ se dirigió al emperador por carta para que interviniese contra el derramamiento de sangre cristiana, hecho que provocó el envío por parte de Adriano de una carta a su sucesor, Minucio Fundano, procónsul en 122-124, para que cesasen las condenas de cristianos sólo por su nombre y se juzgase sólo a los que hubiesen cometido algún delito concreto. Es un gran cambio frente a la dura postura de Trajano, que respondía a Plinio que había que ejecutar a todo aquel que reconociese ser cristiano, es decir, "sólo por el nombre", independientemente de que hubiera cometido algún delito o no, sin miramientos hacia la edad, el sexo o la condición social del procesado. Esta carta de Adriano fue citada también por Justino (1 Apol. 68, 6-19), por lo que no cabe dudar de su historicidad. De hecho, es este cambio radical en la política imperial con respecto a los cristianos lo que permite que el obispo Quadrato de Atenas y el filósofo Arístides puedan presentarse ante el emperador en el año 124-125, cuando se encontraba de nuevo en la ciudad para visitar a sus amigos de la familia Filopapos e iniciarse en los misterios de Eleusis.

Adriano había conocido a Gayo Julio Antíoco Filopapos y a su hermana Julia Balbila, hijos del último rey de Commagene y de una mujer egipcia llamada Claudia Capitolina emparentada igualmente con la familia real de Commagene, durante su presencia en Atenas en el 112. Ellos lo iniciaron en el interés por los cultos mistéricos, especialmente el de Eleusis y el de Isis. Con ellos viajaría a Egipto en el 130 para escuchar el cántico de los colosos de Memnón. Probablemente por iniciativa de ellos asumió la ciudadanía ateniense y el cargo de arconte de la ciudad, un cargo menor después de haber asumido el consulado romano en el 108, por el que le hacía un honor a la ciudad más que recibirlo de ella, pero un cargo que pudo ponerle de nuevo en contacto con los cristianos, probablemente ya perseguidos en Atenas durante aquellos años, como lo eran en Bitinia y el Ponto. Tampoco debe olvidarse que unos meses antes Adriano había acudido como estudiante de filosofía a la stoa de Epicteto en Nicópolis, la ciudad fundada por Augusto en la costa dálmata para conmemorar

72. Euseb., Hist. Eccl. IV 9. Ni Trajano ni Adriano aceptaban las delaciones anónimas, pero Trajano aceptaba que se condenase a todo aquel cristiano que no abjurase de su religión mientras que Adriano sólo a aquellos que se probase que hubiesen cometido un delito, proponiendo también castigos para los denunciantes falsos.

73. "Serenus Granius" en la versión latina que hizo Jerónimo del Chronicon, "Serenius Lucidus" en la versión armenia. Véase Petersen, 1970, pp. 58-59, nº 247. 
su victoria de Actium. Y ya se ha mencionado cómo Epicteto trató el tema del fanatismo por el martirio por parte de los "galileos" en sus Diatribas.

En cualquier caso, cuando regresó a Atenas en 124 llevaba ya tres años de emperador y los conocimientos adquiridos en Antioquía durante la Guerra de Qitos, en la que no participaron los cristianos, modificarían probablemente su opinión respecto a los cristianos. Hasta entonces, el fenómeno cristiano era para los romanos una superstitio judía, como la definieron en 111 d.C. Plinio, en 115-116 Tácito y en 121 Suetonio. ${ }^{74}$ En todos estos casos, el término "cristiano" aparece como un calificativo de un grupo humano. Puesto que no existía ni la palabra ni la categoría "paganos", debieron utilizar el calificativo "cristianos" para distinguir a dicho grupo de otros grupos de judíos.

No sabemos nada de la Apología de Quadrato, el obispo ateniense que sucedió en el cargo a Dionisio Areopagita, martirizado quizás en la persecución que terminó con la carta de Minucio Fundano en el 122. Tan sólo que estuvo en presencia del emperador junto al filósofo Arístides. La Apología de este último, sin embargo, se nos ha conservado en dos manuscritos armenios y uno siríaco, además de dos fragmentos interpolados en dos obras literarias posteriores (la novela griega de Barlaam y Joasaf y la obra georgiana El Martirio de Eustatio de Mzchetha), así como en fragmentos papiráceos griegos. ${ }^{75}$ Aunque se ha discutido la datación e incluso hubo una hipótesis

74. Plin., Ep. X 96; Tac., Ann. XV 44, 2-3; Suet., Claud. 25; Ner. 16. Para la datación de la Carta de Plinio sigo a Walsh, 2006, que argumenta contra la datación de Momsen en 112 y de Sherwin-White en 110.

75. Hasta 1878, la Apología de Arístides de Atenas sólo era conocida por lo que mencionaban de ella Eusebio de Cesárea y Jerónimo de Estridón. Ese año los Mequitaristas, monjes del monasterio de San Lázaro de Venecia, publicaron a partir de dos manuscritos armenios una colección de fragmentos de la obra perdida. (Mechitaristae, 1878). Poco después, en 1889, J. Rendel Harris, fellow del Clare College de Cambridge, descubrió un manuscrito en siríaco de la obra en el monasterio del Monte Sinaí, concretamente en el códice 16 de los manuscritos sirios del monasterio. Estaba escrito a dobles columnas y datado en el siglo VII. Incluía toda una serie de tratados o extractos. El libro de Arístides comenzaba a los pies del folio $93^{\text {a }}$ y terminaba en el folio 104b (Harris, 1891, pp. 1-4). Gracias a la traducción de Harris, J. Armitage Robinson descubrió que una novela piadosa atribuida a Juan Damasceno llamada Novela de Barlaam y Joasaf, contenía un fragmento en griego de la Apología, que Robinson publicó como anexo a la obra de Harris en 1891 (pp. 65-118). La editio princeps de esta obra la había realizado Boissonade en 1832 basándose en cuatro códices parisinos, pero existen ciento cuarenta copias de las cuales veintiséis son anteriores al siglo XII, por lo que Calotta Alpigiano ha realizado en 1988 una nueva edición basada en seis códices vaticanos y uno laurentino, cuatro de ellos del siglo XI (Alpigiano, 1988, pp. 38-48.). Por otra parte, en 1901 se publicaban otros fragmentos que habían sido interpolados en una obra georgiana, El Martirio de Eustatio de Mzchetha, del siglo VI (Dschawachoff y Harnack, 1901, pp. 875-902). Finalmente, otros fragmentos griegos fueron apareciendo posteriormente entre los papiros egipcios, el último publicado en el año 2000 (Hagedorn, 2000, pp. 40-44). 
que atrasaba la obra hasta tiempos de Antonino Pío, hoy día es unánime la aceptación de la fecha tradicional atribuida a la obra, entre el 124 y el $125 .{ }^{76}$ Por otra parte, tiene sentido que tanto el obispo Quadrato como el filósofo Arístides aprovecharan la visita del emperador a Atenas producida tras el cese de las persecuciones sufridas por los cristianos en Grecia y Asia (Carta a Minucio Fundano). ${ }^{77}$

La Apología de Arístides denota, sin embargo, una clara dependencia conceptual e ideológica con el aristotelismo, el platonismo medio y el estoicismo, a los que no critica en ningún momento, ${ }^{78}$ cosa que para empezar, debió agradar a Adriano. No debió

76. Según Eusebio (Chronicon ad ann. 125), Arístides entregó su Apología a Adriano junto al obispo Quadrato en el año $9^{\circ}$ de su imperio, en la $226^{a}$ olimpiada, es decir, en 125. Según un manuscrito armenio de la obra de Eusebio (códice N), las dos apologías fueron entregadas a Adriano en la olimpiada $226^{a}$, pero en el año $8^{\circ}$ de su imperio, es decir, entre 124 y 125 .Nada añade Eusebio en $H$. E. IV, 3,3. Pero Jerónimo en Martirologium Vetus Romanum (PL 123,344; 374) menciona que tras la muerte de Dionisio Areopagita en tiempos de Adriano, Arístides dirigió su obra al emperador; y añade que el 31 de agosto se conmemoraba la muerte de Arístides (aunque curiosamente los Martirologios griegos ignoran a Arístides), e incluso comenta que defendió él mismo su Apología en presencia del emperador; por último, en Epist. 70, 4 ad Magnum añade que Justino imitó a Arístides enviando a Antonino Pío y a sus hijos y al Senado otra apología. El fragmento armenio de la Apología comienza así: Al emperador Adriano César, de Arístides, filósofo de Atenas. El título del manuscrito sirio es Apología hecha por Arístides el filósofo ante Adriano el Rey. Inmediatamente después viene una segunda introducción que dice: ... César Tito Adriano Antonino, Augustos y Píos, de Marciano Arístides filósofo de Atenas. A pesar de que las palabras "augusto" y "pío" van en el manuscrito acompañadas del signo sirio para el plural y de que hay una clara laguna antes de "César", Harris se inclinó por datar la obra en época de Antonino Pío. Argumentaba que, si se admitiera que originalmente habría sido dirigida Al emperador Elio Adriano Augusto César y a Tito Adriano Antonino, tendría que considerarse el año 138 como fecha de la obra, lo que se contradice con la datación eusebiana durante la visita a Eleusis (Harris, 1891, pp. 7-9). Un razonamiento extraño, ya que al datarla en época de Antonino también se contradice la datación eusebiana. Aunque la hipótesis de Harris ha tenido algún seguimiento en el siglo XX, la mayoría de los expertos considera que la obra debe datarse en época de Adriano, como testimoniaron Eusebio y Jerónimo en el siglo IV, y no en época de Antonino o de Adriano y Antonino, que sólo se basan en un manuscrito del siglo VII. Ni siquiera tiene sentido la hipótesis conciliadora de Hennecke que propuso que la obra fue dedicada primero a Adriano en el 138 y al morir este a Antonino, ya que, para empezar, aquel año Antonino aún no dentaba el título de Pío, y además los testimonios papirológicos son claros: la obra fue dedicada a un sólo augusto (Hennecke, 1893, pp. 103-105). Es más razonable concluir que el copista siríaco se confundió al incluir en su códice esa extraña referencia a Antonino, quizás porque había estado trabajando antes con la Apología de Justino. Los testimonios a favor de la datación en el 124-125 son más numerosos y coherentes. Una variante moderna de esta hipótesis, igualmente artificial, es la de la segunda edición de la obra (la primera en 124-5, la segunda en 140-5): Grant, 1988, pp. 38-39. Véase el debate en Pouderon y Pierre, 2003, pp. 32-37, sin duda, la mejor edición de la obra hasta la fecha.

77. Griffe, 1967. Aristid., Apol. 15, 6; Euseb., Hist. Eccl. IV 3, 1-2; Jeron., Martirologium Vetus Romanum PL 123, 344; 374

78. Lazzati, 1938, pp. 35-51. 
costarle trabajo al emperador comprender términos como pronoia, agennetos, autogenes eidos, anarkhon, athanaton, akataleptos, anonomastos, akromatos, amorfos, etc; vocabulario claramente protognóstico que denota bastante proximidad con el lenguaje de la Sophia Jesu Christi. ${ }^{79}$ Pero nada debió entender, sin embargo, de la cristología de Arístides. ${ }^{80}$ No podemos saber si le interesaron la escatología y la caridad, ${ }^{81}$ pero sospechamos que le importaría poco la condena de la religión judía por su culto a los ángeles (14,4 Sy). Es muy probable que le molestara la impertinente crítica al politeísmo en su presencia, ${ }^{82}$ aunque debía estar acostumbrado por sus estudios filosóficos a las sátiras que los propios sabios griegos hicieron de sus mitos. Sin embargo, le agradaría la defensa que Arístides hizo de la ética ciudadana de los cristianos, cuyas actividades políticas y sociales poco tendrían que ver con las de los judíos, que tantos conflictos estaban ocasionando en diversas provincias del Imperio. Probablemente a Arístides no sólo le interesaba que el emperador percibiese a los cristianos como un grupo religioso helenizado, aceptable en la sociedad romana, sino que también pretendía que sus propios correligionarios se percibiesen a sí mismos como ciudadanos respetables del Imperio (la obra no sólo estaba destinada al emperador, evidentemente, de ahí que las comunidades cristianas conservasen copias de la misma). La explicación de la ética y

79. Pap.Berol. 8502. Cf. Alpigiano, 1988, p. 130.

80. Probablemente Arístides era subordinacionista y no trinitario. Nunca califica a Cristo como Dios. El Espíritu Santo no aparece en la versión siríaca. Sí en 2,4 Ar y en 15,1 Ba, pero debemos aplicar el método de la Lectio difficilior y considerar estas últimas interpolaciones de los copistas para adecuar la obra a la ideología triunfante (Apol. 2, 3-4 Sy $+\mathrm{Ar}=14,1$ y 15, $1 \mathrm{Ba}$; 1, 1-2 Sy $+\mathrm{Ar}+\mathrm{Ba}$ ). Hay una fórmula trinitaria completa en 15, $3 \mathrm{Ba}$, pero debe ser una interpolación del copista bizantino. Carlotta Alpigiano considera que es preferible el texto griego aunque admite que contiene términos como "oikonomía", que sólo aparece en la fórmula trinitaria a partir del Símbolo de Constantinopla del 360. Alpigiano 1988, 23-27. Ante esta discreción que observa Arístides sobre la Trinidad, Bernard Pouderon y Marie-Joseph Pierre exclaman piadosamente que no significa que fuera un adepto al monarquianismo o al subordinacionismo, sino que se explica por la necesidad de exponer a los paganos el contenido de la doctrina cristiana lo más claramente posible (p. 68). No estoy de acuerdo en absoluto. Se trata de una especulación piadosa sin base alguna. Pocos años después, Justino expondría ante Antonino el dogma trinitario (1Apol. 61). Lo razonable es pensar que Arístides no conocía dicho dogma, como no lo conocían los autores cristianos anteriores.

81. Alusiones a la caridad cristiana 1, 2 Ar; 15,5 Sy; 15, 4 Ba. Una alusión a la resurrección de los muertos en la interpolacion bizantina de 15,3 Ba; a la resurrección de Cristo en 2, $4 \mathrm{Sy}+\mathrm{Ar}=15,1 \mathrm{Ba}$; y a la naturaleza inseparable de cuerpo y alma en 7,1 Sy.

82. Arístides crítica, entre otros, el culto a los dioses con los que más se identificaba Adriano: Zeus, Apolo, Dionisios, Hércules, Diana e Isis. Es muy probable que ignorara las inclinaciones del emperador, pero es notorio su silencio respecto a Démeter, la diosa de Eleusis, a la que evita mencionar probablemente por respeto a la visita de Adriano al santuario. En cualquier caso, las críticas son muy superficiales y menores que las de los escépticos. 
ciudadanía cristiana se realizaba en contraposición a la degradación moral de la época, un tópico también de la literatura aristocrática romana, que reivindica el retorno a la virtus de los antepasados: frente a la generalización del adulterio, la prostitución y la homosexualidad, el cristiano tenía una moral sexual ordenada y siempre dentro del matrimonio, cosa que interesaba destacar porque era un lugar común de la legislación imperial y de la moral tradicional romana que la sociedad debía basarse en la familia virtuosa. Obviamente porque las familias cuya sexualidad se reducía al matrimonio eran más procreadoras y el Imperio necesitaba una mayor natalidad, tema que preocupaba desde Augusto. Con lo cual, los cristianos eran buenos ciudadanos en el sentido de dar hijos al Imperio. Pero no sólo eso, además respetaban las leyes, no cometían delitos contra la propiedad ni de violencia. Respetaban a las autoridades instituidas por el emperador. Eran pacíficos y sumisos. Todo ello, en aquella época de rebeliones judías, los hacía interesantes para el Imperio. ${ }^{83}$

Por otra parte, el objetivo principal de Arístides consistía en desligar la identidad cristiana de la identidad judía, tanto en la mente del emperador como en la de los lectores gentiles e incluso entre los posibles lectores judeocristianos. Véase contra quién se dirige la disertación: "Dichas estas cosas acerca de Dios, tal como yo he alcanzado a hablar sobre Él, pasemos también al género humano, para ver quiénes de entre los hombres participan de la verdad y quiénes del error. Porque para nosotros es evidente, ¡oh rey!, que hay tres géneros de hombres en este mundo: los adoradores de los entre vosotros llamados dioses, los judíos y los cristianos; y a su vez, los que veneran a muchos dioses se dividen también en tres géneros: los caldeos, los griegos y los egipcios, porque estos fueron los guías y maestros de las demás naciones en el culto y adoración de los dioses de muchos nombres". ${ }^{84}$ Lógicamente, para referirse a los politeístas el ateniense no usa el término "helenismo", cuyo significado en la koiné

83. A algunos investigadores les extraña que Arístides dirigiera un escrito criticando la homosexualidad al emperador Adriano que justo por aquel entonces, en el 123, se había llevado consigo al efebo Antinoo. En primer lugar, resulta incluso ridículo pensar que Arístides ni el resto de los ciudadanos de Atenas estuvieran al tanto de la vida sexual del emperador. En segundo lugar, a veces se pierde de vista que el concepto de homosexualidad de griegos y romanos no era el mismo que hoy día, ya que lo único que veían negativamente griegos y romanos era el afeminamiento tanto en las formas y actitudes como en la práctica sexual, prefiriendo ser penetrado que penetrar. Y con casi total seguridad, ni Trajano ni Adriano ni Alejandro Magno eran afeminados, porque no se les hubiera permitido siquiera acceder al poder. En cualquier caso, los judíos y los cristianos condenaban tanto al que era penetrado como al que penetraba, pero Arístides no entra en detalles de este tipo. Por otra parte, Adriano estaba tan influido por la moral de la sociedad de su época como cualquier otro, como demuestra el hecho de que destituyera a Suetonio de su cargo de secretario ab epistuli tras descubrir en Bath (Inglaterra) que había mantenido relaciones con su esposa, pero no lo castigara públicamente para guardar las apariencias.

84. Ap. 2, según fragmentos griegos. Traducción de Ruiz Bueno, 1979b. 
ya se ha mencionado, y tampoco, en consecuencia, "judaísmo" ni "cristianismo", conceptos que desconocía. Sí usa una palabra que se aproxima a la categoría de "politeís-

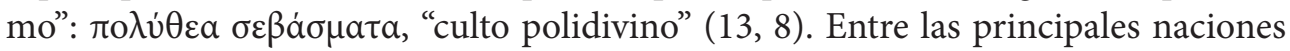
o etnias que promovieron el politeísmo, el texto siríaco añade a fenicios $(11,4 ; 9,1$ Sy) y frigios (11, 5 Sy). Se trata, en cualquier caso, de comparar a los cristianos con las principales naciones en crear religiones, y al final, concluir que los cristianos son el $\varepsilon \Leftrightarrow \theta$ oc que posee la verdad, mientras que "las demás naciones, en cambio, yerran y a sí mismas se engañan" $(16,1 c)$. Por otra parte, culpa del absurdo del politeísmo fundamentalmente a los poetas y los filósofos, ${ }^{85}$ también clasificados de caldeos, griegos y egipcios (13, 2-3), criticándolos por adorar elementos corruptibles $(3,2)$, por el uso de la exégesis alegórica para hacer razonables los mitos paganos $(13,6)$, y por sus ataques contra el Señor $(17,3)$.

En lo que se refiere a los judíos, la cuestión es más compleja, ya que la versión griega de Baarlam y Josafat es más dura hacia ellos que la versión siríaca, acusándolos de pueblo infiel e incrédulo que traicionaba constantemente a su Dios, atendiendo sólo a lo carnal y no al espíritu de la letra (14, 2-4 Ba), alusión esta última claramente paulina (2Co 3, 6; Rom 2, 25-29; 1Co 7, 19; Ga 5, 6), cosa que extraña en una obra que no tiene ni una sola cita de ni un solo libro del Nuevo Testamento y que sólo usa como Escritura el Antiguo Testamento, con preferencia por la Torá o Pentateuco y, en todo caso, por el Libro de los Dos Caminos, ${ }^{86}$ por lo que es lógico deducir que se trata de interpolaciones antijudías del escriba bizantino. Por otra parte, si la versión siríaca no tiene estas alusiones, la griega no contiene las críticas que hace Arístides al ritualismo judío y a su culto a los ángeles y las fiestas (14, 3-4 Sy). Aquí lo más probable, aplicando el principio de la lectio difficilior, es que la crítica al culto a los ángeles sonara herética a oídos del escriba bizantino de la Novela de Barlaam y Josafat, y que fuera él quien suprimió y transformó el pasaje en cuestión con referencias veterotestamentarias y paulinas. En cualquier caso, tanto el texto siríaco como el armenio contienen claras críticas a los judíos por deicidas (2, 4 Sy + Ar), distinguiendo "judío" de "hebreo", identidad esta tratada positivamente por su filantropía y por su linaje desde Moisés hasta María y Jesús (2, 3-4 Sy + Ar). El objeto de distinguir entre judío y hebreo es claro: los judeocristianos y los judíos no cristianos o fariseos son dos pueblos (religiones) que tienen un origen común, pero los judeocristianos representan la parte positiva de ese linaje (Moisés, María, Jesús) mientras los judíos fariseos son

85. Ap. 13, 3. Pouderon y Pierre, 2003, pp. 49-58.

86. Apol. Arist. $15 \mathrm{Ba}=$ Didajé 4, 13; 2, 1-2; 1, 2; 4, 3; 1, 3; 3, 7-8 = Bern 19, 2.10; 19, 4, 6; 19, 5; 19, 4; 20, 2. Y Apol. Arist. 16, $1 \mathrm{Ba}=\operatorname{Did} 1,1=$ Bern 19, 1 . 
los herederos de los que condenaron a los profetas y a Jesús y adoraron a los ídolos en momentos de debilidad. Porque lo que Arístides quería era crear una nueva identidad, "un nuevo pueblo" (16, 3 Sy). No se trataba, como en una lectura apresurada podría percibirse, de idear una identidad propia para los cristianos gentiles, ya que a los judeocristianos también se les incluía en este nuevo ě $\theta v o \varsigma$, de ahí la distinción entre judío y hebreo. Aquellos hebreos de linaje que profesaban el cristianismo pertenecían ya al nuevo pueblo cristiano, mientras que se calificaba de pueblo judío a aquellos hebreos que no habían aceptado a Cristo.

En una línea aún más dura se manifestaría el autor de la Carta de Bernabé, escrita para evitar la conversión al judaísmo rabínico - y por tanto la circuncisión - de aquellos cristianos gentiles a los que algunos maestros judíos llevaban la noticia de la inminente reconstrucción del Templo. Se trata de una obra atestiguada por primera vez en Clemente de Alejandría y que según la mayoría de los expertos fue escrita en esa misma ciudad. ${ }^{87} \mathrm{Y}$ conviene recordar los tremendos enfrentamientos entre la comunidad judía y la griega de Alejandría en el 117, que sin duda dividiría a los cristianos alejandrinos, aproximándose muchos judeocristianos a la causa judía, pero también algunos cristianos gentiles que en cierto modo consideraban a los judíos como correligionarios, pues los límites, como decía Boyarin, aún no estaban claros. Este texto se asemeja a Clemente Alejandrino tanto en el pensamiento protognóstico (Sofía y Gnosis en 2, 2) como en el método alegórico: es quizás el primer escrito cristiano que aplica sistemáticamente dicho método a los textos veterotestamentarios para despojarlos del sentido judío. Fue redactado justo en el momento en que Adriano iniciaba las obras de reconstrucción del Templo, probablemente despejando la explanada de ruinas, es decir, en el 129 o el 130, tal como el mismo autor dejó claro: "Y por remate otra vez les dice (Isaías): He aquí que los que han destruido este templo, ellos mismos lo edificarán. Así está sucediendo, pues por haberse ellos sublevado, fue derribado el templo por sus enemigos, y ahora hasta los mismos siervos de sus enemigos lo van a reconstruir" ${ }^{88}$ Algunos autores han querido llevar la fecha de composición de Bernabé a un período anterior basándose en la cita en 4, 4-5 de la profecía del capítulo 7 de Daniel sobre los diez reinos, de modo que según unos se escribió en

87. Nos interesa aquí sólo la primera parte, los capítulos I-XVII, que se han conservado no sólo en las versiones completas en griego (Códice Sinaítico del s. IV y Códice Bryennios), sino también en una versión latina del siglo X actualmente en la Bibioteca Imperial de San Petersburgo, interesante esta última porque no contiene los capítulos XVIII-XXI que, a todas luces, son una interpolación procedente del "Libro de los Dos Caminos", uno de los textos más antiguos del cristianismo, usado también por la Didajé.

88. Ber 16, 3-4. Traducción de Ruiz Bueno, 1979, pp. 803-804. 
época de Domiciano, según otros de Nerva (el cuerno pequeño que humillaría a los diez emperadores anteriores, dependiendo de si se cuentan a todos los emperadores del año 69 o sólo a los que gobernaron en Egipto). Pero lo mismo vale para datarla en época de Adriano si entendemos la profecía de la siguiente forma: la cuarta bestia se identifica con Augusto, conquistador de Egipto y fundador del Imperio, los diez cuernos que de él brotaron son los emperadores que gobernaron Egipto después de él, sin contar a los rivales de Vespasiano en el año 69 (Tiberio, Calígula, Claudio, Nerón, Vespasiano, Tito, Domiciano, Nerva, Trajano y Adriano), el "rey pequeño" o "cuerno pequeño como un retoño" que humilló de un golpe a tres reyes, sería el Mesías, que acabaría con la dinastía de Nerva-Trajano-Adriano. En cualquier caso, no considero esta cita como una prueba de datación importante, ya que evidentemente puede forzarse según la fecha que se le quiera dar al texto, como es obvio, ya que el pensamiento alegórico del autor de la carta permite perfectamente cualquier tipo de especulación sobre la cita de Daniel. La datación debe hacerse, en todo caso, en función de la cita de la reconstrucción del Templo.

La carta aborda desde el principio esta cuestión, tras la presentación del capítulo 1: "Como quiera, pues, que los días son malos y el poder está en manos

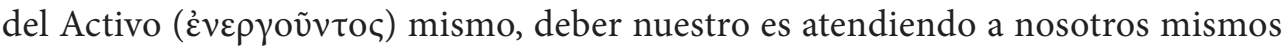
inquirir las justificaciones del Señor (...). En efecto, el Señor, por medio de todos sus profetas, nos ha manifestado que no tiene necesidad ni de sacrificios ni de holocaustos ni de ofrendas" (2, 1-4), y a continuación cita Isaías 1, 11-13; 58, 4-10. Posteriormente, en los capítulos 7 y 8 , realiza una interpretación alegórica disparatada de los preceptos de Levítico y Números relativos a los sacrificios templarios del macho cabrío y el novillo rojo con intención clara de mantener el respeto al Pentatéuco desvinculándolo del culto al Templo. En el capítulo 9 combate la circuncisión citando de nuevo a Isaías, el pasaje en que menciona la necesidad de circuncidar los corazones (Is 33, 12) y otros pasajes proféticos, añadiendo después: "En conclusión, circuncidó nuestros oídos a fin de que, oída la palabra, creamos nosotros. Por lo demás, la misma circuncisión en que ponen su confianza está anulada, porque el Señor habló de que se practicara una circuncisión, pero no de la carne. Mas ellos transgredieron su mandamiento, pues un ángel malo los engañó (...) Pero diréis: es que el pueblo se circuncida para sello. Mas también -te contestaré- se circuncidan los sirios y los árabes y todos los sacerdotes de los ídolos, finalmente, también los egipcios se circuncidan" (11, 4-6), para finalizar interpretando la circuncisión de los 318 miembros de la casa de Abraham como una alusión numérica a las iniciales de Jesús y a la Cruz. El mismo método alegórico le sirve para combatir las prescripciones alimenticias con argumentos tan peregrinos como que la liebre multiplica cada año su ano o que la hiena cambia cada año de sexo (10, 6-7). Aparte de los ar- 
gumentos en pro de la presencia en el Antiguo Testamento de profecías y símbolos relativos a la venida, el bautismo y la pasión de Jesús, nos interesa destacar por último la encendida defensa que el autor realiza de la total independencia del "pueblo" cristiano con respecto al judío, en una línea similar a lo ya visto en Ignacio, 1Pedro y Arístides, aunque sin utilizar nunca ni la palabra cristiano ni la palabra judío: "no os asemejéis a ciertas gentes que, amontonando pecados a pecados, andan diciendo que la Alianza es de aquellos y nuestra. Nuestra, ciertamente, pero aquellos la perdieron en absoluto (...) Además, hermanos míos, considerad este punto: cuando estáis viendo que, después de tantos signos y prodigios sucedidos en medio de Israel y que, sin embargo, han sido de este modo abandonados" (4, 6b-14); "Mas veamos si es este pueblo ( $\lambda$ aò $\varsigma$ ) o es el primero el que hereda, o si el Testamento nos pertenece a nosotros o a ellos (...) Moisés, pues, recibió la Alianza, mas ellos no se hicieron dignos. Ahora bien, ¿cómo la recibiremos nosotros? Aprendedlo: Moisés la recibió como siervo que era, mas a nosotros nos la dio el Señor en persona para hacernos, habiendo sufrido por nosotros, pueblo de su herencia (...) un pueblo santo" $(13,1-14,6)$.

Sobran los comentarios. Si cada pueblo tenía su religio, como se decía al principio del artículo, los cristianos ya eran un pueblo distinto al judío, con su religio propia. Un pueblo sin un territorio propio, sin un país de referencia, un pueblo que nunca tuvo un Estado propio, un pueblo que se extendía por múltiples provincias del Imperio e incluso fuera del Imperio. Algo muy excepcional. Algo difícilmente aceptable para griegos y romanos. Pero al fin y al cabo, ya había un pueblo así, el pueblo judío, que había perdido patria y Estado. Ambos eran pueblos sin patria pero con su propia religio. Con el tiempo la identidad religiosa sería compatible con una identidad étnica diversa, de modo que un individuo pudiera considerarse cristiano y romano, cristiano y griego, o cristiano y germano. Pero de momento, los apologistas y escritores cristianos de la época tuvieron éxito en lograr un cambio decisivo en la mente de las autoridades romanas: que distinguieran entre judíos y cristianos, dos identidades diferentes.

Tras la Guerra de Bar Kokhba, tema que he tratado en otro lugar, ${ }^{89}$ el emperador Adriano prohibió la presencia de judíos circuncidados en Jerusalén y su región, la pequeña Judea, pero no la presencia de cristianos. Los fariseos trasladaron sus escuelas a Galilea, mientras al sur, en las regiones dominadas por Jerusalén y Cesarea, proliferaban los cristianos gentiles y aquellos judeocristianos que abandonaron la circuncisión. Sería un error histórico considerar que Adriano no era consciente de lo que

89. Giménez de Aragón, 2019b. 
hacía diferenciando entre judíos y cristianos. No podemos ignorar el conocimiento que el emperador tuvo a lo largo de su vida del hecho judío y del hecho cristiano. Es mucho más factible que sus medidas estuvieran guiadas por el objetivo que presidió su política: crear una identidad romana cosmopolita. Los fariseos se resistían a toda helenización que fuera en detrimento de la civilización judía. Los cristianos, por el contrario, habían comenzado ya a abandonar los elementos más rígidos de la religio judía que constituían obstáculos para su integración en la sociedad del Imperio (la circuncisión, el sábado, el culto al Templo, los preceptos alimenticios). Quizás pensó que el problema judío se acabaría si favorecía a los judíos cristianos y samaritanos frente a los fariseos. Se equivocó. Pero su política religiosa (prohibiendo vivir en Jerusalén a los judíos circuncidados y no a los cristianos incircuncisos, así como cesando toda persecución a los cristianos) no sólo favoreció la romanización (y helenización) del cristianismo, sino que permitió el desarrollo de un fenómeno nuevo, no ya étnico, sino religioso, que acabaría produciendo la cristianización de Roma, su conversión en capital de la religio que rendía culto a aquel judío de Galilea y de una institución que, desde Ignacio de Antioquía, se denominaría "Iglesia Católica". 


\section{Bibliografía}

Alpigiano, C. (1988). Aristide di Atene. Apologia. Florencia: Edizioni dehoniane.

Alvar, J., Gonzales, A. y Giménez de Aragón, P. (2007). Didáctica del buen comportamiento. El magisterio de la sumisión en el Nuevo Testamento. Studia Historica, Historia Antigua, 25, pp. 397-415.

Applebaum, S. (1974). Domitian's Assassinatio: The Jewish Aspect. Scripta Clasica Israelica, 1, pp. 116-123.

Ayán Calvo, J.J. (1999). Cartas de Ignacio de Antioquía, Carta de Policarpo de Esmirna y Carta de la Iglesia de Esmirna a la Iglesia de Filomeno. Madrid: Ciudad Nueva.

Barnes, T.D. (1989). Trajan and the Jews. En Journal of Jewish Studies, 40, pp. 145-62,

Baslez, M.-Fr. (2007). Les persécutions dans l'Antiquité: victimes, héros, martyrs. París: Fayard.

Beare, Fr.W. (1947). The First Epistle of Peter: The Greek Text with Introduction and Notes. Oxford: Basil Blackwell.

Belayche, N. (2001). Iudaea-Palestina: The Pagan Cults in Roman Palestine. Tubinga: Mohr Siebeck.

Birley, A. (2010). Adriano. Madrid: Gredos.

Blanco, V. y Orlandis, J. (1954). Textos Latinos: Patrísticos, Filosóficos, Jurídicos. Pamplona: Universidad de Navarra.

Bonnet, C., Pirenne-Delforge, V. y Praet, D. (eds.) (2009). Les religions orientales dans le monde grec et romain: Cent ans après Cumont (1906-2006). Bruselas y Roma: Belgisch Historisch Instituut te Rome.

Boyarin, D. (1994). A Radical Jew: Paul and the Politics of Identity. Berkeley: University of California Press.

Boyarin, D. (2001). Justin Martur Invents Judaism. Church History, 70, n ${ }^{\circ}$ v3, pp. 427-461.

Boyarin, D. (2004a). The Christian Invention of Judaism: The Theodosian Empire and the Rabbinic Refusal of Religion. Representations, 85, pp. 21-57.

Boyarin, D. (2004b). Border Lines: The Partition of Judaeo-Christianity. Filadelfia: University of Pennsylvania Press.

Boyarin, D. (2012). The Jewish Gospel. The Story of the Jewish Christ. Nueva York: New Press.

Brent, A. (2006). Ignatius of Antioch and the Second Sophistic. A Study of an Early Christian Transformation of Pagan Culture. Tubinga: Mohr Siebek.

Brent, A. (2007). Ignatius of Antioch. A Martyr Bishop and the Origin of Episcopacy. Londres: T\&T Clark International.

Broghton, T.R.S. (1933). Note XXXIII. The Roman Army. En Foakes y Lake, 1933, p. 442.

Canto, A. (2003). Las raíces béticas de Trajano. Los Traii de la Itálica turdetana y otras novedades sobre su familia. Sevilla: Rd.

Caro, R. (1634). Antigüedades y principado de la ilustrísima ciudad de Sevilla y chorografía de su conventi jurídico o antigua chancillería. Sevilla: Andrés Grande

Cortés, J.M., Muñiz, E. y Gordillo, R. (2011). Grecia ante los imperios. V Reunión de historiadores del mundo griego. Sevilla: Universidad de Sevilla.

Cothenet, E. (1984). Las cartas de Pedro. Estella: Verbo Divino. 
Cothenet, E. (1988). La Première de Pierre: bilan de 35 ans de recherches. ANRW, 25.5, pp. 3685-3712.

Cruz Andreotti, G. (ed.) (2019). Tras los pasos de Momigliano. Centralidad y alteridad en el mundo greco-romano. Barcelona: Bellaterra.

Dabrowa, E. (1993). Legio X Fretensis. A prosopographical study of its officers (I-III A.D.). Stuttgart: Franz Steiner Verlag.

Den Boer, W. et al. (1973). Romanitas et Christianitas. Amsterdam: North-Holland.

Dindorf, L. (1831). Ioannis Malalae Chronographia. Bonn: Ed. Weberi.

D’Ors, Á. (1974). Licinio Silvano, patrono de Badalona. Emérita, 42, nº41, pp. 69-76.

Droyssen, J.G. (1834). Geschichte des Hellenismus, Berlín: F. Perthes (segunda edición de 1877-1878).

Dschawachoff, J., Harnack, A. von (1901). Das Martyrium des Eustatius von Mzchetha. Sitzungsberichte der Königlich preussischen Akademie der Wissenschaften, 38, pp. 875-902.

Dupertuis, R.R. y Penner, T. (eds.) (2013). Engaging Early Christian History. Reading Acts in the Second Century. Durham: Acumen.

Dupont-Sommer, A. (1939). Le quatrième livre des Maccabées. París: H. Champion.

Elliott, J.H. (2000). 1 Peter. A New Translation with Introduction and Commentary. Nueva York: Double Day.

Elliott, J.H. (2013). La Primera Carta de Pedro. Salamanca: Sígueme.

Evans, J.D.R. (2011). From mountain to icon: Mount Gerizim on Roman provincial coins from Neapolis, Samaria. Near Eastern Archaeology, 74.3, pp. 170-182.

Foakes, Fr.J. and Lake, K. (1933). The beginning of Christianity. Vol. V. Part 1. The Acts of Apostles. Eugene: MacMillan \& Co.

Garciadiego, A. (1953). Katholiké Ekklesía. El significado del epíteto "Católica" aplicado a la "Iglesia” desde san Ignacio de Antioquía hasta Orígenes. México: Jus.

Gildemeister, J. (1889). Antonini Placentini Itinerarium. Berlín: H. Reuther.

Giménez de Aragón, P. (2011). Revisión del mapa de Judea y la Decápolis (ss. I a.C.-II d.C.). En Cortés, Muñiz, y Gordillo, 2011, pp. 345-360.

Giménez de Aragón, P. (2019a). Helenización del Judaísmo y Judaización del Helenismo. En Cruz Andreotti, 2019, pp. 57-85.

Giménez de Aragón, P. (2019b). Adriano contra Bar Kosiba, apóstata del helenismo. Gerión 37/1, pp. 117-148.

Gonzalbes, E. (1992). Roma y las tribus indígenas de la Mauritania Tingitania. Un análisis historiográfico. Florentia Iliberritana, 3, pp. 271-302.

Gonzalbes, E. (2010). La provincia romana de la Mauritania Tingitania. Algunas visiones actualizadas. Gerión, 28, 31-51.

González, J. (ed.) (1998). Trajano emperador de Roma. Roma: L'Erma di Bretschneider.

González Salinero, R. (2005). Las persecuciones contra los cristianos en el Imperio Romano: una aproximación crítica. Madrid: Signifer Libros.

Gordillo, R. (2012). La construcción religiosa de la Hélade Imperial: el Panhelenion. Florencia: Firenze University Press.

Grant, R.M. (1988). Greek Apologists of the Second Century. Londres: SCM. 
Griffe, E. (1967). Les persécutions contre les chrétiens aux I et II siècles. París: Letouzey et Ané. Gryson, R. (1929). Les Lettres attribuées à Ignace d'Antioche et l'apparition de l'épiscopat monarchique. Revue Théologique de Louvain, 10, pp. 446-453.

Hagedorn, D. (2000). Ein neues Fragment zu P.Oxy. XV 1778 (Aristide Apologie). Zeitschrift für Papyrologie und Epigraphik, 131, pp. 40-44.

Halleux, A. de (1982). L'Ėglise catholique dans la Lettre ignacienne aux Smyrniotes. Ephemerides Theologicae Lovanienses, 58, pp. 5-24.

Harnack, A. (1929). Die Briefsammlung des Apostels Paulus und die andaren vorkonstantinischen christlichen Briefsammlungen. Leipzig: Hinrichs'sche Buchhandlung.

Harris, J.R. (1891). The Apology of Aristides on behalf of the christians. From a syriac manuscript preserved on the Mount Sinai. Cambridge: Cambridge University Press.

Hennecke, E. (1893). Zur Frage nace der ursprünglichen Textegestalt der Aristides-Apologie. Zitschrift für Wissenschaftliche Theologie, 36, pp. 103-105.

Honigman, S. (2014). Tales of High Priests and Taxes. The Books of the Maccabees and the Judean Rebellion against Antiochus IV. Oakland: University of California Press.

Hübner, R. y Vincent, M. (1999). Der Paradox Eine: antignostischer Monarchianismus im zweiten Jahrhundert. Leiden: Brill.

Jobes, K.H. (2005). 1Peter. Grand Rapids: Baker Academic.

Lazzati, G. (1938). Ellenismo e cristianesimo. Il primo capitolo dell'Apologia de Aristide. La Scuola Cattolica, 66, pp. 35-51.

Lechner, T. (1999). Ignatius Adversus Valentinianos?: Chronologische Und Theologiegeschichtliche Studien Zu Den Briefen Des Ignatius Von Antiochien. Leiden: Brill.

Lighfoot, J. (1883-1889). The Apostolic Fathers, II, v. 2, Londres: Baker Book House.

Lörincz, B. (2001). Die römischen Hilfstruppen in Pannonien während der Principatszeit. Teil I Die Inschriften. Viena: Forschungsgesellschaft Wiener Stadtarchäologie.

McArthur, A. (1961). The Office of Bischop in the Ignatian Epistles and in the Didascalia Apostolorum Compared. Studia Patristica IV (pp. 298-304). Berlín: Akademie-Verlag.

McArthy, J.M. (1971). Ecclesiology in the Letters of St. Ignatius of Antioch: A Textual Analysis. American Benedictine Review, 22, pp. 319-325.

Mason, S. (2007). Jews, Judeans, Judaizing, Judaism: Problems of Categorization in Ancient History. Journal for the Study of Judaism, 38, pp. 457-512.

Mathhews, S. (2010). Perfect Martyr: The Stoning of Stephen and the Legacy of Paul. Oxford: Oxford University Press.

Mechitaristae (1878). Sancti Aristidis philosophi Atheniensis sermones duo. Venecia: S. Łazar.

Miller, S.S. (1996). Hellenistic and Roman Sepphoris: The Historical Evidence. En Nagy, 1996, pp. 21-27.

Mor, M. (2016). The Second Jewish Revolt. The Bar Kokhba War, 132-136 CE. Leiden: Brill.

Mount, Chr. (2002). Pauline Christianity: Luke-Acts and the Legacy of Paul. Leiden: Brill.

Muñiz, E. (2009). The Cult of the Egyptian Gods in Roman Athens. En Bonnet, PirenneDelforge y Praet, 2009, pp. 325-341.

Nagy, R.M. (ed.) (1996). Sepphoris in Galilee: Crosscurrents of Culture. Winona Lake: North Carolina Museum of Art. 
Nashrallah, L. (2008). The Acts of the Apostles, Greek Cities, and Hadrian's Panhellenion. Journal of Biblical Literature, 127, pp. 533-566.

O' Neill, J.C. (1961). The Theology of Acts in Its Historical Setting, Londres: S.P.C.K.

Penner, T. (2004). In Praise of Christian Origins. Stephen and the Hellenists in Lukan Apologetic Historiography. Nueva York: T\&T Clark International.

Pervo, R. (2006). Dating Acts: Between the Evangelist and the Apologist. Santa Rosa: Polebridge Press.

Petersen, L. (1970). Q. Licinius Siluanus Granianus. En Prosopographia Imperii Romani, I, pp. 58-59.

Pouderon, B. y Pierre, M.-J. (2003). Aristide. Apologie. París: Cerf.

Ramsay, W.M. (1896). Cornelius and the Italic Cohort. The Expositor, 5.4, pp. 194-201.

Rius-Camps, J. (1977). Las cartas auténticas de Ignacio, el obispo de Siria. Revista Catalana de Teologia, 2, pp. 31-149.

Ruiz Bueno, D. (1979a). Padres Apostólicos. Madrid: Biblioteca de Autores Cristianos.

Ruiz Bueno, D. (1979b). Padres apologetas griegos. Madrid: Biblioteca de Autores Cristianos.

Saddington, D.B. (1982). The Development of the Roman Auxiliary Forces from Caesar to Vespasian (49 BC-79 AD). Harare: University of Zimbabwe.

Santos Yanguas, N. (1981). Plinio, Trajano y los cristianos. Revista de filología clásica y hebrea, 32, pp. 391-410.

Shellard, B. (2002). New Light on Luke. Its Purpose, Sources and Literary Context. Nueva York: Sheffield Academic Press.

Sherwin-White, A.N. (1966). The Letters of Pliny. Oxford: Clarendon Press.

Schoedel, W.R. (1980). Are the Letters of Ignatius of Antioch Authentics?. RelStR, 6, pp. 196201.

Schoedel, W.R. (1985). Ignatius of Antioch. A Commentary of the Letters of Ignatius of Antioch. Filadelfia: Fortress Press.

Smallwood, E.M. (1962). Atticus, legate of Judaea under Trajan. Journal of Roman Studies, 52, pp. 131-133.

Speidel, M. (1992). Roman Army Studies, v. II. Stuttgart: Franz Steiner Verlag.

Suárez, A. (2005). Trajano y la tercera persecución. Anuario Jurídico y Económico Escurialense, 28, pp. 609-640.

Syme, R. (1962). The Wrong Marcius Turbo. Journal of Roman Studies, 52, pp. 87-96.

Trevett, Chr. (1983). Prophecy and Anti-Epsicopal Activity. A Third Error Combatted by Ignatius?. Journal of Ecclesiastical History, 34, pp. 1-18.

Teja, R. (1998). Conquirendi non sunt: Trajano, Plinio y los cristianos. En González, J., 1998, pp. 475-490.

Tyson, J.B. (2006). Marcion and Luke-Acts: a defining struggle. Columbia: University of South Carolina Press.

Valero, J.B. (1993). San Jerónimo. Epistolario. Madrid: Biblioteca de Autores Cristianos.

Vanacker, W. (2013). Ties of Resistance and Cooperatio. Aedemon, Lusius Quietus and the Baquates. Mnemosyne, 66.4-5, pp. 708-733.

Walsh, P.G. (2006). Pliny the Younger. Complete Letters. Oxford: Oxford University Press. 